\title{
Advances on Food-Derived Peptidic Antioxidants-A Review
}

\author{
Mingfei Pan ${ }^{1,2}$, Kaixin Liu ${ }^{1,2}$, Jingying Yang 1,2, Shengmiao Liu ${ }^{1,2}$, Shan Wang ${ }^{1,2}$ and \\ Shuo Wang 1,2 ,*
}

1 State Key Laboratory of Food Nutrition and Safety, Tianjin University of Science and Technology, Tianjin 300457, China; panmf2012@tust.edu.cn (M.P.); Liukx2019@163.com (K.L.); yangjy0823@126.com (J.Y.); 1sm20000711@outlook.com (S.L.); wshan0929niu@163.com (S.W.)

2 Key Laboratory of Food Nutrition and Safety, Ministry of Education of China, Tianjin University of Science and Technology, Tianjin 300457, China

* Correspondence: s.wang@tust.edu.cn; Tel.: +86-022-60912493

Received: 5 August 2020; Accepted: 24 August 2020; Published: 27 August 2020

check for updates

\begin{abstract}
The oxidation process is considered to be the main reason behind human aging, human degenerative diseases and food quality degradation. Food-derived peptidic antioxidants (PAs) have wide sources and great activity, and have broad application prospects in removing excess reactive oxygen species in the body, anti-aging and preventing and treating diseases related to oxidative stress. On the other hand, PAs are expected to inhibit the lipid peroxidation of foods and increase the stability of the food system in the food industry. However, the production pathways and action mechanism of food-derived PAs are diverse, which makes it is difficult to evaluate the performance of PAs which is why the commercial application of PAs is still in its infancy. This article focuses on reviewing the preparation, purification, and characterization methods of food-derived PAs, and expounds the latest progress in performance evaluation and potential applications, in order to provide an effective reference for subsequent related research of PAs.
\end{abstract}

Keywords: food-derived peptidic antioxidants; purification; characterization; performance evaluation

\section{Introduction}

Since the theory of free radicals was proposed, more and more studies have proved that the degenerative changes in the aging process are related to the production of reactive oxygen species (ROS) such as superoxide anion radical $\left(\mathrm{O}_{2}{ }^{\bullet-}\right)$, hydroxyl radical $\left({ }^{\bullet} \mathrm{OH}\right)$, lipid radical $\left(\mathrm{ROO}^{\bullet}\right)$ and reactive nitrogen species such as nitrogen oxide $\left(\mathrm{NO}^{\bullet}\right)$ during cellular metabolism [1-3]. Generally, free radicals in the body are continuously generated, and there also exists a defense system, composed of endogenous antioxidants (glutathione (GSH), etc.) and antioxidant enzymes (superoxide dismutase (SOD), glutathione peroxidase (GSH-Px), peroxidase, etc.), to maintain the normal metabolic balance of ROS and further protect the body from free radical damage [4,5]. However, when the body ages or is in a bad environment, free radicals are excessively produced or removed slowly, causing oxidative stress [6]. Oxidative stress can cause oxidation of the substances that constitute cell tissues such as lipids, carbohydrates, proteins, and DNA, resulting in oxidative damage such as denaturation, cross-linking, and breakage [7,8]. A large number of studies have demonstrated that many organ dysfunctions or tissue lesions such as heart disease, stroke, arteriosclerosis, diabetes, and cancer are related to the increased content of ROS in the body $[9,10]$. Therefore, it is necessary to seek exogenous antioxidants that can maintain the balance of free radical metabolism in the body together with the endogenous antioxidant system to adjust and improve human physiological functions, so as to achieve the purpose of preventing and treating chronic diseases [11,12]. Additionally, unfavorable factors 
such as heat, light-sensitive transition metals, metal proteins and radiation can lead to food lipid peroxidation, that cause changes in food quality such as color, smell, tissue structure and nutritional components and result in a decline in food quality and even the production of harmful substances [13]. Therefore, it is necessary to add antioxidants in the production process to maintain food quality (especially for meat products) [14]. Synthetic antioxidants with strong antioxidant effects such as 2,6-Di-tert-butyl-4-methylphenol (BHT) and butylhydroxyanisole (BHA) are restricted or prohibited due to the potential teratogenic and carcinogenic effects on the human body [15].

Recently, the development of high-efficiency and safe antioxidants from natural products, especially foods, has become one research hotpot and has attracted widespread attention from researchers. Except for some well-known natural antioxidants (such as vitamins, bioflavonoids, carotenoids, proteins, amino acids, etc.), peptides also have the same antioxidant mechanism [16,17]. Compared to amino acids and macromolecular proteins, peptides with a structure between them have extremely biological diversity and more significant antioxidant properties. In addition, peptidic antioxidants (PAs) can be ingested safely, and usually possess other biological activities such as antibacterial, anti-hypertensive and cholesterol reduction [18-21]. Based on the above advantages, PAs have become potential raw materials for the development of new functional foods, health products, and food additives. Some PAs are naturally present in foods. However, due to the low content and limited sources, the extraction operation of such peptides is complicated and costly, which makes it difficult for industrial production and commercial application. Studies have shown that peptide sequences with antioxidant activity are often found in food proteins (edible proteins, and waste proteins in food processing), and they need to be released through certain technologies (Figure 1) [22,23]. Due to the wide sources and abundant content of precursor proteins, these types of PAs can greatly improve the economic benefits of the food industry and promote environmental protection, with a wide range of practical applications (Figure 1) [24,25].

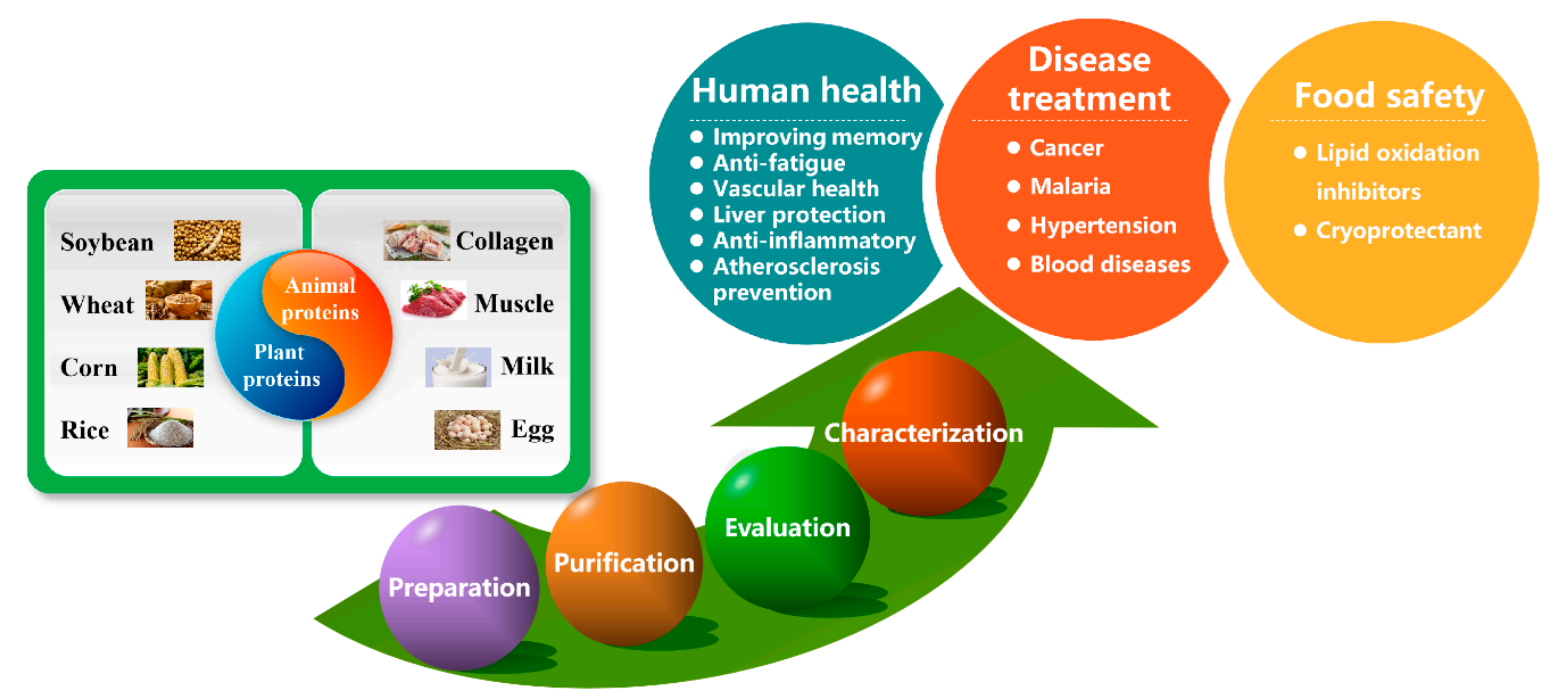

Figure 1. Protein sources, research methods and potential applications of peptidic antioxidants.

This article reviews the latest advances of PAs in foods and food processing by-products, especially the methods of preparation, purification, and characterization, and also summarizes the structure-activity relationship (SAR) of PAs derived from food proteins. Additionally, due to the complexity of the antioxidant mechanism of bioactive peptides, this article comprehensively analyzes the main methods for PA performance evaluation and summarizes its application prospects in food-related fields in order to provide a certain reference for the subsequent research of PAs. 


\section{Preparation of PAs Derived from Food Proteins}

The protein in foods is an important source of PAs, and the bioactive peptides can be released by suitable degradation means from the proteins [26]. At present, the methods for producing PAs through degrading proteins mainly include enzymatic hydrolysis, gastrointestinal (GI) digestion, and microbial fermentation and other food processing [27].

\subsection{Enzymatic Hydrolysis}

Enzymatic hydrolysis is a method for preparing PAs by using endogenous or exogenous proteases to degrade food proteins [28]. Because the conditions of the hydrolysis process are relatively mild and easy to control, enzymolysis is currently the most frequently used strategy in preparing PAs, developing new PAs and studying the SAR of PAs [29,30]. Table 1 illustrates the PAs prepared by enzymatic hydrolysis using edible animal and plant proteins as raw materials in recent years. The SAR indicates that the PA properties are mainly related to the molecular weight $(\mathrm{Mw})$, the composition of amino acids and hydrophobicity [31,32]. The types of food proteins and enzymes directly affect the structure of PAs. Soybean protein [33-35], wheat protein [36], corn protein [37], rice protein [38] of plant origin and muscle protein [39,40], collagen [41], milk protein [42], egg protein [43] of animal origin have been used for the preparation of PAs. Additionally, the parameters of time, added amount, temperature and $\mathrm{pH}$ may affect the degree of hydrolysis (DH) of the substrate proteins, which further affect the size and amino acid composition of the obtained peptides [44,45]. Due to the different targets and cleavage methods of enzymes, the kinds and properties of enzymes are crucial to the preparation of PAs by hydrolysis [46]. Compared to the endogenous enzymes, exogenous proteases have higher hydrolysis efficiency and are controllable for hydrolyzed products [47]. In the early days, proteases were selected by comparing the antioxidant properties of hydrolysates obtained under optimal conditions through preliminary biochemical experiments [48]. Wattanasiritham et al. used Trypsin and Papain to hydrolyze rice bran protein (RBP), in which the RBP hydrolyzed by Trypsin had the highest antioxidant activity [49]. Although this strategy is blind and needs a cumbersome experimental process, it is still the main way to develop new PAs and improve the system of SAR. With the deepening of SAR research, databases related to PAs have been gradually constructed, and the quantitative SAR (QSAR) bioinformatics have also been gradually applied to proteases selection and exploration of new PAs [50,51]. Esfandi et al. compared the effect of different enzymes on the extraction and hydrolysis to oat bran proteins by peptide analysis method and antioxidant activity measurement [52]. The results showed that Viscozyme-proteins hydrolyzed with Papain showed stronger antioxidant capacity. The effect of 21 different enzymes and enzyme combinations on the release of potential PAs in major yolk protein of sea urchin Strongylocentrotus nudus was analyzed by in silico analysis [53]. From the obtained results, the Proteinase K, Papain and GI tract enzymes have the best hydrolysis effect (the number of peptides effectively released are 20,16 and 13-15, respectively). The use of bioinformatics can transform the tedious, time-consuming and high-cost process of exploring new PAs into a simple, systematic, and designable one, which has wide application prospects [54]. 
Table 1. Enzymes used for the preparation of food protein hydrolysate, the methods of purification, and the evaluation of antioxidant capacity ${ }^{1}$.

\begin{tabular}{|c|c|c|c|c|c|}
\hline Source & $\begin{array}{c}\text { Enzyme and Purification } \\
\text { Methods }\end{array}$ & In Vitro Chemical Evaluation & $\mathrm{IC}_{50}$ or Scavenging Activity ${ }^{2}$ & $\begin{array}{c}\text { Amino Acid Sequence or } \\
\text { Molecular Weight }\end{array}$ & Ref \\
\hline $\begin{array}{l}\text { Egg white } \\
\text { protein powder }\end{array}$ & $\begin{array}{l}\text { Alcalase; UF (30, 10, } 1 \text { kDa), } \\
\text { GFC (Sephadex), RP-HPLC }\end{array}$ & $\begin{array}{c}\text { Reducing power assay } \\
\text { DPPH radical scavenging activity } \\
\text { ABTS radical scavenging activity } \\
\text { ORAC assay }\end{array}$ & $\begin{array}{l}\text { ABTS }(92.21 \pm 0.5 \% \text { at } 5 \mathrm{mg} / \mathrm{mL}) \\
\text { ORAC }(1238.56 \pm 0.6 \mu \mathrm{mol} \mathrm{TE} / \mathrm{g}) \\
\text { DPPH }(\text { FFGFN IC } 50=80 \mathrm{mM} ; \\
\left.\text { MPDAHL } \mathrm{IC}_{50}=60 \mathrm{mM}\right)\end{array}$ & $\begin{array}{l}\text { DHTKE, FFGFN, } \\
\text { MPDAHL }\end{array}$ & [55] \\
\hline $\begin{array}{l}\text { Duck (Anas } \\
\text { platyrhynchos) } \\
\text { breasts }\end{array}$ & $\begin{array}{l}\text { Protamex; UF (30, } 10 \text { kDa), } \\
\text { GFC (Sephadex G-25), IEC }\end{array}$ & $\begin{array}{l}\text { DPPH radical scavenging activity } \\
\cdot \mathrm{OH} \text { scavenging activity } \\
\mathrm{Fe}^{2+} \text { chelating activity }\end{array}$ & $\begin{array}{c}\text { DPPH }(93.63 \pm 0.13 \% \text { at } \\
1.0 \mathrm{mg} / \mathrm{mL})\end{array}$ & $\begin{array}{l}\text { LQAEVEELRAALE, } \\
\text { IEDPFDQDDWGAWKK, } \\
\text { AGRALTAYLMKIL, } \\
\text { GYDLGEAEFARIM }\end{array}$ & [56] \\
\hline Chickpea seeds & $\begin{array}{l}\text { Pepsin, Pancreatin; AC, } \\
\text { GFC, nanofiltration }\end{array}$ & $\begin{array}{c}\text { Reducing power assay } \\
\text { DPPH radical scavenging activity }\end{array}$ & - & $\begin{array}{c}\text { ALEPDHR, } \\
\text { TETWNPNHPEL, FVPH, } \\
\text { SAEHGSLH }\end{array}$ & [57] \\
\hline $\begin{array}{l}\text { Rice residue } \\
\text { protein }\end{array}$ & $\begin{array}{c}\text { Papain, Flavourzyme, } \\
\text { Protamex; GFC (Sephadex } \\
\text { G-15), RP-FPLC }\end{array}$ & $\begin{array}{c}\text { DPPH radical scavenging activity } \\
\text { ABTS radical scavenging activity } \\
\text { FRAP-Fe }^{3+} \text { reducing } \\
\text { capacity assay }\end{array}$ & $\begin{array}{l}\mathrm{DPPH}(77.6 \% \text { at } 0.5 \mathrm{mg} / \mathrm{mL}, \\
\left.\quad \mathrm{IC}_{50}=0.25 \mathrm{mg} / \mathrm{mL}\right)\end{array}$ & $\begin{array}{l}\text { RPNYTDA, TSQLLSDQ, } \\
\text { TRTGDPFF, NFHPQ }\end{array}$ & [58] \\
\hline Rice bran protein & Trypsin; RP-HPLC & ORAC assay & ORAC $(4.07 \mu \mathrm{mol} \mathrm{TE} / \mathrm{g})$ & $800-2100 \mathrm{Da}$ & [49] \\
\hline $\begin{array}{l}\text { Pinto bean } \\
\text { protein isolate }\end{array}$ & $\begin{array}{c}\text { Protamex; UF }(100,50,30,10, \\
3 \mathrm{kDa})\end{array}$ & $\begin{array}{c}\text { ABTS radical scavenging activity } \\
\text { FRAP assay }\end{array}$ & $\begin{array}{c}\text { ABTS }(42.2 \% \text { at } 7 \mathrm{mM}) ; \text { FRAP } \\
(0.81 \mathrm{mM})\end{array}$ & $\begin{array}{c}\text { PPHMLP, PPMHLP, } \\
\text { PLPPHMLP, PLPLHMLP, } \\
\text { ACSNHSPLGWRGH, } \\
\text { LSSLEMGSLGALFVCM }\end{array}$ & [59] \\
\hline Pearl millet & $\begin{array}{l}\text { Trypsin; GFC (Sephadex } \\
\text { G-25), RP-UFLC }\end{array}$ & $\begin{array}{c}\text { DPPH radical scavenging activity } \\
\text { ABTS radical scavenging activity } \\
\mathrm{Fe}^{2+} \text { chelating activity } \\
\text { Reducing power assay } \\
\bullet \text { OH scavenging activity }\end{array}$ & $\begin{array}{l}\text { DPPH }(67.66 \% \text { at } 1 \mathrm{mg} / \mathrm{mL}) \\
\text { ABTS }(78.81 \% \text { at } 1 \mathrm{mg} / \mathrm{mL})\end{array}$ & SDRDLLGPNNQYLPK & [60] \\
\hline
\end{tabular}


Table 1. Cont.

\begin{tabular}{|c|c|c|c|c|c|}
\hline Source & $\begin{array}{c}\text { Enzyme and Purification } \\
\text { Methods }\end{array}$ & In Vitro Chemical Evaluation & IC $_{50}$ or Scavenging Activity ${ }^{2}$ & $\begin{array}{c}\text { Amino Acid Sequence or } \\
\text { Molecular Weight }\end{array}$ & Ref \\
\hline $\begin{array}{l}\text { Palmaria palmata } \\
\text { protein }\end{array}$ & $\begin{array}{l}\text { Corolase }^{\circledR} \text { PP; SPE, } \\
\text { SP-RP-HPLC }\end{array}$ & ORAC assay, FRAP assay & $\begin{array}{c}\text { ORAC }(4380.75 \pm 66.44 \mu \mathrm{mol} \\
\text { TE/g dw }) ; \text { FRAP }(51.86 \pm \\
1.85 \mu \mathrm{mol} \mathrm{TE} / \mathrm{g} \mathrm{dw})\end{array}$ & SDITRPGGQM & [47] \\
\hline Oat glutelin & Alcalase; IEC, RP-HPLC & $\begin{array}{l}\bullet \mathrm{OH} \text { scavenging activity } \\
\text { DPPH radical scavenging activity }\end{array}$ & $\bullet \mathrm{OH}\left(\mathrm{IC}_{50}=0.68 \mathrm{mg} / \mathrm{mL}\right)$ & HYNAPAL & [61] \\
\hline $\begin{array}{l}\text { Egg in fresh } \\
\text { Apostichopus } \\
\text { japonicus }\end{array}$ & $\begin{array}{c}\text { Papain, Protamex; UF, } \\
\text { HSCCC; GFC (Sephadex } \\
\text { G-100, G-50) }\end{array}$ & $\begin{array}{l}\bullet \\
\mathrm{O}_{2}^{\bullet-} \text { scavenging activity }\end{array}$ & $\begin{array}{l}\bullet \mathrm{OH}(93.26,70.04 \text {, and } \\
89.82 \mathrm{U} / \mathrm{mL} \text {, respectively) }\end{array}$ & $\begin{array}{l}30 \mathrm{kDa} \text { (3 kinds } \\
\text { of peptides) }\end{array}$ & [62] \\
\hline Hazelnut protein & $\begin{array}{l}\text { Alcalase; GFC (Sephadex } \\
\text { G-25, G-15), RP-HPLC }\end{array}$ & $\begin{array}{l}\text { DPPH radical scavenging activity } \\
\text { ABTS radical scavenging activity }\end{array}$ & $\begin{array}{l}\text { DPPH }(69.2 \pm 1.2 \%) \\
\text { ABTS }(92.9 \pm 1.0 \%)\end{array}$ & $\begin{array}{l}\text { ADGF, AGGF, AWDPE, } \\
\text { DWDPK, ETTL, SGAF }\end{array}$ & [63] \\
\hline $\begin{array}{l}\text { Pecan protein } \\
\text { isolate }\end{array}$ & $\begin{array}{l}\text { Alcalase; UF (10, 5, } 3 \text { kDa), } \\
\text { IEC, GFC (Sephadex G-50) }\end{array}$ & $\begin{array}{l}\text { DPPH radical scavenging activity } \\
\text { ABTS radical scavenging activity } \\
\text {-OH scavenging activity } \\
\text { Reducing power assay } \\
\mathrm{Fe}^{2+} \text { chelating activity }\end{array}$ & $\begin{array}{c}\text { DPPH, ABTS, } \bullet \text { OH } \\
\text { (LAYLQYTDFETR: } 56.25 \%, \\
67.67 \%, 47.42 \% \text { at } 0.1 \mathrm{mg} / \mathrm{mL} \text { ) }\end{array}$ & LAYLQYTDFETR & [23] \\
\hline $\begin{array}{l}\text { Sheep } \\
\text { abomasum } \\
\text { protein }\end{array}$ & $\begin{array}{c}\text { Papain; UF (10, } 3 \text { kDa), IEC; } \\
\text { GFC (Sephadex G-50), } \\
\text { RP-HPLC }\end{array}$ & $\begin{array}{l}\text { DPPH radical scavenging activity } \\
\text { ABTS radical scavenging activity } \\
\bullet^{\circ} \mathrm{OH} \text { scavenging activity }\end{array}$ & $\begin{array}{c}\text { DPPH (LEDGLK: } \text { IC }_{50}= \\
0.63 \mathrm{mg} / \mathrm{mL} ; \text { IDDVLK: } \mathrm{IC}_{50}= \\
0.58 \mathrm{mg} / \mathrm{mL})\end{array}$ & LEDGLK, IDDVLK & [64] \\
\hline $\begin{array}{l}\text { Erythrina edulis } \\
\text { (pajuro) protein }\end{array}$ & $\begin{array}{c}\text { Alcalase; Polyamide SPE, } \\
\text { RP-HPLC }\end{array}$ & $\begin{array}{c}\text { ABTS radical scavenging activity } \\
\text { ORAC assay }\end{array}$ & $\begin{array}{l}\text { ABTS }(1.37 \pm 0.09 \mu \mathrm{mol} \mathrm{TE} / \mathrm{mg}) \\
\text { ORAC }(2.83 \pm 0.07 \mu \mathrm{mol} \mathrm{TE} / \mathrm{mg})\end{array}$ & $\begin{array}{l}\text { DGLGYY, CCGDYY, } \\
\text { YDLHGY }\end{array}$ & [65] \\
\hline
\end{tabular}


Table 1. Cont.

\begin{tabular}{|c|c|c|c|c|c|}
\hline Source & $\begin{array}{c}\text { Enzyme and Purification } \\
\text { Methods }\end{array}$ & In Vitro Chemical Evaluation & $\mathrm{IC}_{50}$ or Scavenging Activity ${ }^{2}$ & $\begin{array}{c}\text { Amino Acid Sequence or } \\
\text { Molecular Weight }\end{array}$ & Ref \\
\hline $\begin{array}{l}\text { Finger millet } \\
\text { protein }\end{array}$ & Trypsin; UF, GFC, RP-UFLC & $\begin{array}{c}\text { DPPH radical scavenging activity } \\
\text { ABTS radical scavenging activity } \\
\mathrm{Fe}^{2+} \text { chelating activity } \\
\bullet \mathrm{OH} \text { scavenging activity }\end{array}$ & $\begin{array}{c}\text { DPPH, ABTS, } \mathrm{Fe}^{2+} \text { chelating, } \\
{ }^{\circ} \mathrm{OH}(61.79 \%, 78.61 \%, 51.20 \% \\
66.66 \% \text { at } 1.0 \mathrm{mg} / \mathrm{mL})\end{array}$ & $\begin{array}{l}\text { TSSSLNMAVRGGLTR } \\
\text { STTVGLGISMRSASVR }\end{array}$ & {$[66]$} \\
\hline $\begin{array}{l}\text { Cutlassfish } \\
\text { muscle }\end{array}$ & $\begin{array}{l}\text { Pepsin; UF, GFC (Sephadex } \\
\text { G-25), RP-UFLC }\end{array}$ & $\begin{array}{c}\text { DPPH radical scavenging activity } \\
\text { Peroxyl radical } \\
\text { scavenging activity }\end{array}$ & $\begin{array}{l}\text { DPPH }\left(\mathrm{IC}_{50}=0.03 \mathrm{mg} / \mathrm{mL}\right) \\
\text { Peroxyl }\left(\mathrm{IC}_{50}=0.02 \mathrm{mg} / \mathrm{mL}\right)\end{array}$ & FSGE & {$[67]$} \\
\hline $\begin{array}{l}\text { Sea squirt } \\
\text { protein }\end{array}$ & Pepsin; GFC, RP-HPLC & $\begin{array}{c}\text { DPPH radical scavenging activity } \\
\text { ABTS radical scavenging activity } \\
\text { ORAC assay } \\
\text { Reducing power assay } \\
\mathrm{Fe}^{2+} \text { chelating activity }\end{array}$ & $\begin{array}{c}\text { DPPH }\left(\mathrm{LEW}: \mathrm{IC}_{50}=1.29 \mathrm{mM}\right) \\
\mathrm{Fe}^{2+}(\mathrm{LEW}, \mathrm{MTTL}, \mathrm{YYPYQL}: \\
9.20-12.5 \% \text { at } 1 \mathrm{mM})\end{array}$ & MTTL, LEW, YYPYQL & {$[68]$} \\
\hline $\begin{array}{l}\text { Freeze-dried } \\
\text { stone fish flesh }\end{array}$ & $\begin{array}{l}\text { Alcalase; UF, SDS-PAGE, } \\
\text { RP-HPLC, Isoelectric point } \\
\text { focusing fractionation }\end{array}$ & $\begin{array}{c}\text { DPPH radical scavenging activity } \\
\text { ABTS radical scavenging activity } \\
\text { FRAP }\end{array}$ & $\mathrm{DPPH}(62.5 \%$ at $0.1 \mathrm{mg} / \mathrm{mL})$ & GVSGLHID & [69] \\
\hline $\begin{array}{l}\text { Wheat germ } \\
\text { protein }\end{array}$ & Alcalase; RP-HPLC & ABTS & - & $\begin{array}{l}\text { TVGGAPAGRIVME, } \\
\text { GNPIPREPGQVPAY }\end{array}$ & {$[70]$} \\
\hline Sesame protein & $\begin{array}{l}\text { Alcalase, Trypsin; UF }(3,5,8, \\
10 \mathrm{kDa}), \text { prep-HPLC }\end{array}$ & $\begin{array}{l}\text { DPPH radical scavenging activity } \\
\text { ABTS radical scavenging activity }\end{array}$ & $\begin{aligned} \text { DPPH }\left(\mathrm{IC}_{50}\right. & =2.793 \mathrm{mg} / \mathrm{mL}) \\
\text { ABTS }\left(\mathrm{IC}_{50}\right. & =2.949 \mathrm{mg} / \mathrm{mL})\end{aligned}$ & $\begin{array}{l}1008.2-1402.7 \mathrm{Da} \\
\text { (7 kinds of peptide) }\end{array}$ & {$[71]$} \\
\hline $\begin{array}{l}\text { Sea cucumber } \\
\text { collagen }\end{array}$ & $\begin{array}{l}\text { Neutrase; UF (5, } 1 \text { kDa) } \\
\text { GFC (Sephadex G-15) }\end{array}$ & $\begin{array}{l}\text { DPPH radical scavenging activity } \\
\text { ABTS radical scavenging activity }\end{array}$ & $\begin{array}{c}\mathrm{DPPH}(35 \% \text { at } 0.2 \mathrm{mg} / \mathrm{mL}) \\
\text { DPPH }(\mathrm{FLAP} \mathrm{EC} \\
0.385 \mathrm{mg} / \mathrm{mL})\end{array}$ & FLAP & {$[72]$} \\
\hline
\end{tabular}


Table 1. Cont.

\begin{tabular}{|c|c|c|c|c|c|}
\hline Source & $\begin{array}{c}\text { Enzyme and Purification } \\
\text { Methods }\end{array}$ & In Vitro Chemical Evaluation & $\mathrm{IC}_{50}$ or Scavenging Activity ${ }^{2}$ & $\begin{array}{c}\text { Amino Acid Sequence or } \\
\text { Molecular Weight }\end{array}$ & Ref \\
\hline $\begin{array}{l}\text { Tartary } \\
\text { buckwheat } \\
\text { albumin }\end{array}$ & $\begin{array}{c}\text { Alkaline Protease; UF (3, } \\
10 \text { kDa), IEC, GFC (Sephadex } \\
\text { G-15), RP-HPLC }\end{array}$ & $\begin{array}{c}\text { DPPH radical scavenging activity } \\
\bullet \text { OH scavenging activity } \\
\text { Reducing power assay } \\
\text { Lipid peroxidation inhibition }\end{array}$ & $\begin{array}{c}\text { GEVPW, YMENF, AFYRW: } \\
\text { DPPH }\left(\mathrm{IC}_{50}=1.20,2.91\right. \\
0.64 \mathrm{mM}) ;{ }^{\circ} \mathrm{OH}\left(\mathrm{IC}_{50}=2.21,1.56\right. \\
0.65 \mathrm{mM}) ; \text { Reducing power }(0.702 \\
0.554,0.927 \text { at } 4 \mathrm{mg} / \mathrm{mL})\end{array}$ & GEVPW, YMENF, AFYRW & [73] \\
\hline $\begin{array}{l}\text { Duck plasma } \\
\text { powder }\end{array}$ & $\begin{array}{l}\text { Alcalase; UF (10, } 3 \text { kDa), GFC } \\
\text { (Sephadex G-25), RP-HPLC }\end{array}$ & $\begin{array}{c}\mathrm{O}_{2}^{\bullet-} \text { scavenging activity } \\
\text { DPPH radical scavenging activity } \\
\text { ABTS radical scavenging activity } \\
\mathrm{Fe}^{2+} \text { chelating activity } \\
\text { Reducing capacity }\end{array}$ & $\begin{array}{c}\text { DPPH }(88.36 \% \text { at } 1.0 \mathrm{mg} / \mathrm{mL}) \\
\mathrm{O}_{2}{ }^{--}(64.47 \% \text { at } 1.0 \mathrm{mg} / \mathrm{mL}) \\
\text { ABTS }(149.67 \mathrm{mM} \mathrm{TE} / \mathrm{mg} \text { at } \\
1.0 \mathrm{mg} / \mathrm{mL})\end{array}$ & $\begin{array}{l}\text { LDGP, TGVGTK, EVGK, } \\
\text { RCLQ, LHDVK, KLGA, } \\
\text { AGGVPAG }\end{array}$ & {$[74]$} \\
\hline
\end{tabular}
(RP-HPLC); 2,2-Diphenyl-1-picrylhydrazyl (DPPH); 2,2-azino-bis (3-ethylbenzothiazoline-6-sulphonic acid) diammonium salt (ABTS); Oxygen radical absorbance capacity (ORAC); affinity chromatography (AC); ferric reducing antioxidant power (FRAP); reverse phase fast protein liquid chromatography(RP-FPLC); ion exchange chromatography (IEC); hydroxyl Radical $\left({ }^{\bullet} \mathrm{OH}\right)$; sodium dodecyl sulfate polyacrylamide gel electrophoresis (SDS-PAGE); superoxide anion radical $\left(\mathrm{O}_{2}{ }^{\circ-}\right)$; solid phase extraction (SPE); semi-preparative reverse phase-high performance liquid chromatography (SP-RP-HPLC); reversed phase ultra flow liquid chromatography (RP-UFLC); high-speed countercurrent chromatography (HSCCC); preparative HPLC (prep-HPLC). ${ }^{2}$ If there is no special label, the antioxidant evaluation data listed here is the data of the peptide fraction with the strongest antioxidant capacity after purification. 
At present, the enzymes commonly used in the preparation of food-derived PAs mainly include microbial-derived industrial proteases (Alcalase, Flavourzyme, Protamex and Neutral Proteases), plant-derived proteases (Papain) and animal-derived proteases (Pepsin and Trypsin) [75] (Table 1). Some proteases for the hydrolysis of specific food proteins have been applied for the development of PAs. For example, collagenase can specifically hydrolyze collagen to obtain peptides with high antioxidant activity [76,77]. In addition, some newly developed proteases have also been applied to hydrolyze proteins to prepare PAs. Metalloproteases and Serine proteases have been respectively prepared from fungus Eupenicillium javanicum and Myceliophthora thermophila [78]. These two proteases were used to digest egg albumin, casein, and whey protein, and new PAs were separated and purified from the three protein hydrolysates. Since the hydrolysis of proteases is carried out at specific sites, single enzymes have a relatively small range of hydrolysis, and complex hydrolysis of two or more proteases will often achieve more effective results [79]. The multi-enzyme hydrolysis process is mainly divided into biphase sequential enzymolysis mode, two-step enzymolysis mode and their combined method [80]. Zhang et al. used a mixed enzyme (Papain:Protamex =1:1) and Flavorzyme to hydrolyze egg extract in sea cucumber (Apostichopus japonicus) step by step, and gradually purified the hydrolysate [62]. Finally, a pure PA (Mw: about $30 \mathrm{kDa}$ ) with a high ${ }^{\bullet} \mathrm{OH}$ scavenging capacity of $89.82 \mathrm{U} / \mathrm{mL}$ was obtained.

In industrial production, the preparation of PAs by the traditional enzymatic hydrolysis method has many shortcomings such as the one-time use of enzymes, unstable performance of products from a different batch, long production cycle and high labor intensity [81,82]. Many efforts have been made in continuous hydrolysis modes such as the use of an enzyme membrane reactor (EMR) and the immobilized enzymes for the above shortcomings [83]. EMR is a type of reaction equipment that uses a membrane with an appropriate pore size to separate enzymes and substrates from the products, and allows the products to continuously pass through the membrane, achieving the purpose of simultaneous progress of enzymatic hydrolysis and separation [84,85]. Compared with traditional methods, EMR has many advantages such as continuous operation, reaction-separation coupling, good enzyme stability and reusability, effective enrichment, which improves the catalytic efficiency and product yield [86]. Tanaskovic et al. studied the effect of continuous EMR (ultrafiltration (UF) module $(10 \mathrm{kDa}))$ on Alcalase digestion of egg white protein [87]. The results showed that the continuous EMR can improve and strengthen the enzyme reaction process and enhance 2,2-Diphenyl-1-picrylhydrazyl (DPPH) and 1,1-diphenyl-2-picryl-hydrazyl (ABTS) radical scavenge activity, and ferric reducing antioxidant power (FRAP) of the hydrolysates. The immobilized enzyme technology refers to the establishment of the enzyme in a specific position to maintain its long-term catalytic ability, reusability and controllability of the reaction [88]. Neto et al. used bovine casein as raw material and applied the protease from Penicillium aurantiogriseum immobilization on polyaniline-coated magnetic nanoparticles to prepare PAs [89]. Compared with non-immobilized Trypsin, covalently immobilized Trypsin on functionalized graphene oxide nanosheets exhibited significantly enhanced thermal stability, $\mathrm{pH}$ resistance and activity retention ability, and improved the free radical scavenging activity of the hydrolysate [90].

Appropriate pretreatment technology can promote the release of PAs during enzymatic hydrolysis of food proteins (Table 2) [91-93]. Besides the traditional heat treatment, new treatment strategies such as microwave [94], ultrasound [95], high pressure (HP) [96] and pulsed electric field (PEF) [97] have also been applied to improve the efficiency of enzymatic hydrolysis in the preparation of PAs. The microwave treatment has the advantages of promoting the efficiency of the reaction, strong selectivity, easy operation, fewer by-products, high yield and easy purification of the product [98]. Ketnawa et al. compared the effect of microwave pretreatment and microwave-assisted treatment on the hydrolysis of fish frame protein by Alcalase [99]. The research demonstrated that microwave treatment can significantly improve protein solubility, protein recovery, $\mathrm{DH}$, and ABTS radical scavenging activity. The antioxidant activity of fish peptides prepared by microwave pretreatment $(5 \mathrm{~min})$ followed by conventional enzymatic hydrolysis (2-10 $\mathrm{min})$ is superior to other treatment methods. The ultrasound 
can form the microbubbles in the liquid medium, and its rupture is accompanied by the release of energy, which can affect protein rearrangements and aggregate formation, thereby improving the biological activity of the hydrolysate [100-103]. The effect of ultrasonic and heat treatment on the enzymatic hydrolysis of barley beer waste protein by Alcalase showed that the ultrasonic pretreatment $(50 \mathrm{kHz})$ can increase the antioxidant activity of protein hydrolysates and promote the release of PAs [104]. Under optimal ultrasonic conditions, low-frequency ultrasound-assisted enzymatic hydrolysis can effectively improve $\mathrm{DH}$ and conversion rate of corn protein and the free radical scavenging activity of the hydrolysate, and promote the formation of short-chain peptides (200-3000 Da) containing hydrophobic amino acids [105]. HP pretreatment/auxiliary treatment can increase the hydrolysis rate and DH of the substrate protein, promote the release of low Mw peptides and essential amino acids, and improve the antioxidant activity of the hydrolysate [106], which has been applied to promote the proteolysis process of legume [107,108] and peanut protein [109]. Additionally, high hydrostatic pressure (HHP) also has the ability to improve the efficiency of enzymatic hydrolysis [110]. HHP auxiliary treatment can improve the enzymatic hydrolysis efficiency of Corolase PP, reduce the surface hydrophobicity of the hydrolysate, and increase the production of small peptides [111,112]. PEF is a non-thermal processing technology that is used to sterilize, inactivate enzymes, extract functional active substances, and improve the nutritional value of foods. Therefore, PEF is often used to increase the activity of PAs after food proteolysis and separation of small PAs [113-115]. Studies have shown that PEF does not destroy the stability of PAs, but affects the secondary structures ( $\alpha$-helix, $\beta$-turn and random coil) of peptides and reduces zeta potential [116,117]. In addition, radio frequency pretreatment, high-energy electron beam, and protease co-extrusion technology have also been shown to be beneficial for improving the enzymatic hydrolysis efficiency and activity of PAs [118-120].

Chemical hydrolysis based on acid-base hydrolysis has also been used to prepare PAs. However, due to the destructive effect of this method on amino acids, the great changes in the composition of hydrolysate, and the high production cost, this method has been gradually replaced by enzymatic hydrolysis [121]. Protease enzymolysis has the advantages of mild conditions, specific degradation sites, fast, controllable, high repeatability, and high safety of the product, which is one hotspot in the research of PAs. As mentioned above, new technologies are devoted to develop new PAs more efficiently and accurately and to solve problems in the enzymatic hydrolysis process, such as reducing production costs and maintaining the activity of PAs. However, the current hydrolysis process is usually accompanied by the production of some bitter peptides, which need further research for its removal. 
Table 2. The effect of different pretreatment or co-treatment methods on the preparation of peptidic antioxidants by enzymatic hydrolysis ${ }^{1}$.

\begin{tabular}{|c|c|c|c|c|c|}
\hline Source & Enzyme & $\begin{array}{l}\text { Processing } \\
\text { Method }\end{array}$ & Processing Conditions & Advantages & Ref \\
\hline $\begin{array}{l}\text { Fish frame } \\
\text { protein }\end{array}$ & Alcalase & Microwave & $\mathrm{T}=90^{\circ} \mathrm{C}, \mathrm{t}=5 \mathrm{~min}$ & $\begin{array}{l}\text { Improved protein solubility, protein recovery, } \\
\text { DH, and ABTS radical scavenging activity. }\end{array}$ & [99] \\
\hline $\begin{array}{c}\text { Barley beer } \\
\text { waste protein }\end{array}$ & Alcalase & Ultrasound & Frequency $=50 \mathrm{~Hz}, \mathrm{t}=4 \mathrm{~h}$ & $\begin{array}{c}\text { Improved metal-chelating activity }(54 \%) ; \\
\text { improved DPPH radical, } \mathrm{O}_{2}^{\bullet-} \text { scavenging, } \\
\text { and }{ }^{\bullet} \mathrm{OH} \text { scavenging activity }(28 \%, 18 \%, 25 \%)\end{array}$ & {$[104]$} \\
\hline $\begin{array}{l}\text { Tilapia } \\
\text { by-product } \\
\text { protein }\end{array}$ & Alcalase & $\begin{array}{l}\text { High } \\
\text { pressure-assisted }\end{array}$ & $\begin{array}{l}\text { Pressure }=250 \mathrm{MPa} \\
t=35 \mathrm{~min}\end{array}$ & $\begin{array}{l}\text { Facilitated the release of low Mw peptides and } \\
\text { essential amino acids; improved soluble } \\
\text { protein content }(5.7 \mathrm{mg} / \mathrm{mL}), \mathrm{RP} \\
(44 \mu \mathrm{g} \text { AAE } / \mathrm{g}) \text {, and solubility }(71 \%) \text { of } \\
\text { hydrolysates; decreased } \mathrm{IC}_{50}(\mathrm{DPPH}) \text { values } \\
\text { from } 653 \mu \mathrm{g} / \mathrm{mL} \text { to } 304 \mu \mathrm{g} / \mathrm{mL}\end{array}$ & [106] \\
\hline $\begin{array}{l}\text { Soybean protein } \\
\text { isolate }\end{array}$ & Corolase PP & $\begin{array}{l}\text { High hydrostatic } \\
\text { pressure }\end{array}$ & Pressure $=200 \mathrm{MPa}, \mathrm{t}=4 \mathrm{~h}$ & $\begin{array}{l}\text { Enhanced the efficiency of enzymolysis; } \\
\text { decreased surface hydrophobicity of } \\
\text { hydrolysates; increased the production of } \\
\text { small peptides }(<3 \mathrm{kDa}) \text {; increased } \mathrm{RP} \\
\text { ABTS radical scavenging activity }\end{array}$ & {$[111]$} \\
\hline $\begin{array}{l}\text { Egg white } \\
\text { protein }\end{array}$ & Alcalase & $\begin{array}{l}\text { Pulsed electric } \\
\text { field }\end{array}$ & $\begin{array}{l}\text { Strength }=10 \mathrm{kV} \mathrm{cm}^{-1} \\
\text { pulsed number }=300 \\
\text { frequency }=3000 \mathrm{~Hz}\end{array}$ & $\begin{array}{l}\text { Increased RP ability; broke down larger } \\
\text { peptides into smaller peptides }\end{array}$ & {$[114]$} \\
\hline Pea protein & Papain & $\begin{array}{l}\text { Protease } \\
\text { co-extrusion }\end{array}$ & $\begin{array}{c}\mathrm{E}=12.0 \%, \mathrm{~T}=60.2^{\circ} \mathrm{C}, \mathrm{pH}= \\
6.5, \mathrm{~S}=7.1 \%\end{array}$ & $\begin{array}{l}\text { Enhanced the efficiency of enzymolysis and } \\
\text { DPPH radical scavenging activity }(98.1 \%) \text { of } \\
\text { enzymatic hydrolysate }\end{array}$ & [118] \\
\hline
\end{tabular}


Table 2. Cont.

\begin{tabular}{|c|c|c|c|c|c|}
\hline Source & Enzyme & $\begin{array}{l}\text { Processing } \\
\text { Method }\end{array}$ & Processing Conditions & Advantages & Ref \\
\hline $\begin{array}{l}\text { Sweet potato } \\
\text { protein }\end{array}$ & $\begin{array}{l}\text { Alcalase, } \\
\text { Protease }\end{array}$ & Radio frequency & $\mathrm{T}=80^{\circ} \mathrm{C} / 90^{\circ} \mathrm{C}$ & $\begin{array}{c}\text { Increased } \mathrm{Mw}<3 \mathrm{kDa} \text { peptide fraction and its } \\
\text { antioxidant capacity }\end{array}$ & [119] \\
\hline Rice protein & Alcalase & $\begin{array}{l}\text { High-energy } \\
\text { electron beam }\end{array}$ & Irradiation doses $=30 \mathrm{kGy}$ & $\begin{array}{l}\text { Increased ratio of antioxidative amino acids; } \\
\text { produced smaller peptides; increased DPPH } \\
\text { and ABTS radical scavenging activity ( } 32.06 \% \\
\text { and } 79.11 \% \text { ) of hydrolysates }\end{array}$ & [120] \\
\hline
\end{tabular}

molecular weight $(\mathrm{Mw})$ 


\subsection{Microbial Fermentation and Other Food Processing}

Microbial fermentation is one traditional way of producing and preserving foods, which can increase the nutritional and health value of foods $[122,123]$. Due to the action of microorganisms and endogenous proteolytic enzymes, PAs can be produced during the fermentation process [124,125]. Many kinds of fermented milk have been proven to be an important source of bioactive peptides [126-128]. Four peptides with high antioxidant activity in both chemistry and cell model evaluations have been purified and identified from the pasteurized milk fermented with Lactobacillus acidophilus $\mathrm{NCFM}^{\circledR}$, Lactobacillus delbrueckii subs. bulgaricus and Streptococcus thermophilus [129]. Fermented meat products can also be used as a source of PAs [130]. By mixing and fermenting pork, koji and salt, fermented meat sauce can produce antioxidant tripeptide (Gln-Tyr-Pro) with the ${ }^{\bullet} \mathrm{OH}$ scavenging activity greater than $90 \%$ through the proteolysis process [131]. A dipeptide (Trp-Pro) with high ABTS radical scavenging activity $\left(E C_{50} 17.52 \pm 0.46 \mu \mathrm{M}\right)$ was identified from Thai traditional fermented shrimp paste [132]. The purified component of fermented fish (pekasam) has strong ABTS radical scavenging activity $\left(I C_{50}=0.636 \mathrm{mg} / \mathrm{mL}\right)$, and two new PAs (AIPPHPYP, IAEVFLITDPK) were identified [133]. Compared with the enzymatic hydrolysis method, the fermentation method can simultaneously carry out the enzyme production and enzymatic hydrolysis processes using the microorganism, which reduces the cost. During the fermentation process, the exopeptidase produced by the microorganism has a modification effect on the small peptide end, which not only avoids the generation of bitterness but imparts the natural fermented flavor to the foods. Based on the above, fermented foods are potential sources of PAs. Additionally, microbial fermentation plays an important role in preparing PAs from the by-products of the food industry [134,135]. It has demonstrated that the type of inoculated microorganisms and the maturation time affect the concentration and size of peptides [136]. In the fermentation process, Bacillus subtilis [137,138], lactic acid bacteria (LAB) [139-141] and fungi [142] can release many different kinds of peptides with antioxidant activity. The three small peptides extracted from solid-state fermented sesame meal have demonstrated to have high DPPH radical and $\bullet \mathrm{OH}$ scavenging ability and can reduce the level of malondialdehyde (MDA) in the serum and liver of mice, and improve the liver SOD and GSH-Px activity [143]. At present, there are many studies focused on the exploration and analysis of bioactive components in the microbial fermentation broth, especially antioxidant components [144,145]. However, the research on the technology and mechanism of microbial fermentation to produce PAs still need to be explored.

Protein hydrolysis occurring in other food processing processes will naturally produce large amounts of peptides. This phenomenon is often caused by endogenous enzymes in mature foods [146]. In some processed foods, such as dried shrimp, fish sauce, tuna, ham, pot meat, non-dairy creamer, white bread and noodles, there is a peptide cyclo (His-Pro) with antioxidant activity, which can protect the body from oxidative stress and prevent GSH depletion caused by glutamate, rotenone, paraquat and beta-amyloid treatment $[147,148]$. From Jinhua ham, one peptidic antioxidant (PA) (GKFNV) was purified and identified with strong DPPH radical scavenging activity [149]. Spanish dry-cured ham is considered a good source of natural bioactive peptides [150]. The peptide with an Mw of 464.17 Da (SNAAC) extracted from Spanish dry-cured ham is a good antioxidant [151]. Another PA (AEEEYPDL) identified from Spanish dry-cured ham was found to have good heat and salt resistance [152].

\section{Purification and Identification of PAs}

\subsection{Purification of PAs}

Protein-derived PAs exist at low concentrations in complex systems containing different amino acid compositions. Therefore, suitable separation and purification methods are needed to enrich peptide fragments with high antioxidant activity. At present, the commonly used purification strategies for PAs mainly include membrane and chromatographic separation technology based on the changes of Mw, charge and polarity/hydrophobicity $[153,154]$. The membrane separation technology, containing microfiltration, UF and nanofiltration, is cheap and easy to operate, often applied for the initial 
purification [155]. Among them, UF is currently the most widely used method for separating PAs from food protein hydrolysates (Table 1). The centrifugal UF filters with different Mw cut-off membranes $(100,50,30,10$ and $3 \mathrm{kDa})$ have been used in the separation of hydrolysates of Pinto bean protein isolate [59]. The obtained peptides with $\mathrm{Mw}<3 \mathrm{kDa}$ were demonstrated to have the highest free radical scavenging and FRAP activity. This is because the peptides with lower Mw are more likely to react with lipid radicals, thereby reducing free radical-mediated lipid peroxidation reaction. As mentioned earlier, the continuous integration of EMR in the enzymatic hydrolysis reaction and UF membrane separation can improve the enzymatic hydrolysis process and prepare peptides with satisfactory antioxidant activity. The traditional membrane separation driven by pressure has low selectivity for peptides with similar Mw, and can easily cause membrane contamination at HP. Electrodialysis with filter membrane (EDFM) has increased the electric field as an additional driving force based on the traditional pressure-driven UF, significantly improving the membrane migration efficiency and selectivity [156]. The separation of PAs by EDFM depends on the charge (using the different potential as a driving force for migration) and the $\mathrm{Mw}$ (the screening effect of the filter) of the peptides. Suwal et al. used a two-step continuous EDFM process to directly separate rainbow trout box protein hydrolysate and obtain the cationic and anionic peptides with high antioxidant activity [157]. EDFM is considered to be a more environmentally friendly technology because it does not require the use of solvents in the separation process. However, compared with other membrane separation techniques, the production efficiency of EDFM is lower, warranting further research.

The commonly used chromatography techniques in the separation of PAs include gel filtration chromatography (GFC), ion-exchange chromatography (IEC), reversed-phase high-performance liquid chromatography (RP-HPLC), preparative HPLC (prep-HPLC) and affinity chromatography, among others (Table 1). GFC is an efficient, simple, and gentle separation method based on the difference of $\mathrm{Mw}$, which is mostly used to separate and purify water-soluble polymer substances and is mainly applied in the first stage of separation of PAs [66]. IEC has significant advantages in the separation of different amounts of positive and negative charged peptides $[158,159]$. RP-HPLC is a method of ion exchange using polar media as the main stationary phase, which separates peptides based on Mw and hydrophobicity $[160,161]$. In practical applications, it is usually necessary to combine multiple separation methods to separate the target product, and to avoid the incompatibility of the mobile phase in the multi-dimensional system. Jang et al. combined the UF, prep-HPLC and RP-HPLC to separate and purify sandfish protein hydrolysates and screened PAs in each stage by in vitro chemical evaluation method, where it was demonstrated that the purified polypeptide has higher antioxidant activity than protein hydrolysates [162].

Additionally, surface plasmon resonance (SPR) technology can monitor the interaction between molecules in real-time and offer a label-free detection, which is also considered in screening PAs [163]. Canabady-Rochelle et al. developed an SPR strategy for screening metal-chelating peptides in hydrolysates, which can detect the presence of metal-chelating peptides in hydrolysate faster before starting the separation stage, and has great potential for industrial application [164].

\subsection{PAs Identification and $S A R$}

The identification and characterization are important parts of analyzing the SAR of peptides, which is helpful to verify the reliability of the antioxidant capacity of the screened peptides. Electrophoresis analysis technology, especially sodium dodecyl sulfate polyacrylamide gel electrophoresis, is commonly used to evaluate the $\mathrm{Mw}$ distribution of food proteins or hydrolysates $[165,166]$. Tandem mass spectrometry (MS) technology has become an effective method for analyzing Mw and amino acid sequences of PAs [60,61]. Fourier transform infrared spectroscopy (FT-IR) can be used to study the secondary structure of peptides [167]. The re-synthesis of peptides is a common method to verify the antioxidant capacity of peptides and analyze the SAR [168]. A typical example is the use of nano liquid chromatography-electrospray ionization-tandem MS to characterize seven new peptide sequences with antioxidant activity from the purified components of sesame protein 
hydrolysate [71]. Seven peptides were re-synthesized to verify the antioxidant activity of the identified peptides and nine kinds of SYPTECRMR derived peptides were designed and synthesized to study the SAR of the peptide with the strongest antioxidant activity, and then the QSAR of SYPTECRMR was figured out by a comparative molecular field analysis (CoMFA) model. The results show that the active sites of SYPTECRMR are located in the fragment ECRMR and seem to be related to Cys or Met residues. Moreover, the amino acid sequence SYPT and steric hindrance, electrostatic interaction and other factors will also affect the antioxidant activity of SYPTECRMR. As can be seen above, the study of the SAR can provide a theoretical basis for each link of peptide preparation, which is also supplemented during the preparation process of peptides.

The molecular structure (Mw, amino acid composition, amino acid sequence and molecular conformation) and hydrophobicity of peptides are considered to be closely related to its antioxidant activity [169-171]. Bioactive peptides containing 2-20 amino acid residues and with an Mw in the range of 200-3000 Da are considered to have good antioxidant activity [172,173]. Peptides with lower Mw can interact with radicals more effectively, and it is easier to exert antioxidant capacity through the intestinal barrier in vivo [174]. Dipeptides and tripeptides are considered to be highly potential PAs because they can be absorbed intact from the intestinal lumen into the bloodstream and then produce biological effects at the tissue level [175]. Amino acid composition and specific amino acid sequence are the important factors affecting the antioxidant activity of peptides $[176,177]$. In short, peptides with strong antioxidant activity tend to have a higher proportion of hydrophobic amino acid residues [59]. Because hydrophobic amino acid residues, especially those at the end of the peptide chain, can enhance the solubility of PAs in fats and oils, their aliphatic hydrocarbon side chains can interact with fat molecules, thereby delaying or blocking lipid transition oxidation reaction chain to protect the integrity of lipid system and membrane [178]. The hydrophobicity of the peptides also makes it easier to enter the hydrophobic target organs, thereby exerting antioxidant effects [179]. The side-chain carboxyl group of the acidic amino acid has a hydrogen-donating effect, which can chelate metal ions to weaken the radical chain reaction and achieve the antioxidant effect. Antioxidant amino acid residues such as Tyr, Met, His, Lys, Trp, and Cys are often present in polypeptides with strong antioxidant activity. The imidazole group of His is related to its metal chelation, hydrogen supply and lipid peroxidation capabilities [180]. Cysteine containing thiol can directly interact with radicals, and it has an important contribution to the antioxidant activity of peptides. Due to the specific interaction and relative spatial structure between the amino acids in the amino acid sequence of the peptide, the antioxidant activity of a single amino acid is significantly lower than that of the peptide [181,182].

Since the structure of the peptide and its mechanism of antioxidant action are extremely complex, some researchers tried to summarize the relationship between the structure of peptides and antioxidant activity in order to evaluate the potential of various food proteins as PAs precursors, guiding for the selection of proteolytic enzymes and the design and synthesis of PAs [183,184]. QSAR and in silico bioinformatics methods are effective strategies to achieve these functions $[185,186]$. Huang et al. have combined proteomics technology with BIOPEP analysis to prove that the myosin heavy chain of tilapia processing by-products is a good precursor for PAs [187]. When using bioinformatics to prepare PAs, the update and combination of peptide databases are also important. Deng et al. applied model population analysis to establish a QSAR model on two datasets containing antioxidant tripeptides (FTC and FRAP) [188]. This three-dimensional QSAR model is constructed through CoMFA and comparative similarity index analysis, and can be used to guide the combination design and virtual screening of new peptides [189]. Leung et al. used Proteinase $\mathrm{K}$ to simulate digestion of rye secalin in silico, and used computational analysis based on density functional theory to identify two tripeptides (CQV and QCA) containing cysteine [190]. In silico methods have also been applied to in vivo function prediction of PAs. Alcalase and Trypsin were used to hydrolyze Atlantic sea cucumber, and peptide fractions $(<2 \mathrm{kDa})$ with high antioxidant activity in vitro were separated using UF method [191]. The main antioxidant amino acids of the two peptides and their molecular interaction with myeloperoxidase (MPO) were further analyzed using in silico methods. The results show that Alcalase can produce more peptides 
with both antioxidant amino acids and potential MPO inhibitory activity (35.4\%). A representative peptide sequence TEFHLL produced by Alcalase has a strong molecular interaction with the active site of MPO, which is predicted to have the ability to inhibit oxidative stress in the body.

\section{Strategies for Performance Evaluation of PAs}

Although a lot of research has been performed on PAs, the action mechanism of these kinds of antioxidants has not been fully revealed. Radical scavenging efficacy, metal ion chelation and quenching singlet oxygen are considered to be the main action mechanisms of PAs [168]. Currently, the evaluation of PA performance mainly includes in vitro chemical evaluation, in vitro biological evaluation and in vivo evaluation [192].

\subsection{In Vitro Chemical Evaluation}

Due to the characteristics of easy operation, high efficiency, low toxicity, good reproducibility and short experimental period, in vitro chemical evaluation has become the basic method for screening PAs and quantitatively determining the antioxidant activity of peptides. PAs usually have a complex structure and action principle, resulting in the difficulty of establishing a unified evaluation index [193]. According to different free radical scavenging reaction mechanisms, in vitro chemical models can be divided into the methods based on hydrogen atom transfer (HAT) and electron transfer (ET) [194]. At present, the evaluation methods for in vitro antioxidant activity mainly include DPPH radical scavenging ability, ABTS radical scavenging ability, oxygen radical absorbance capacity (ORAC), and FRAP (Table 1). In addition, evaluation methods based on metal ion $\left(\mathrm{Cu}^{2+}, \mathrm{Fe}^{2+}\right.$, etc.) chelating ability [195,196] and anti-lipid peroxidation ability (thiobarbituric acid reactive substance (TBARS) method, ferric thiocyanate method (FTC), etc.) [197] have also been applied to in vitro chemical models. Studies have found that the antioxidant capacity of the same antioxidant may be different by using evaluation methods based on different mechanisms. For example, the zein hydrolysate obtained by the two-step enzymatic hydrolysis method (Alcalase and Flavourzyme) has higher scavenging values of DPPH radical, ${ }^{\bullet} \mathrm{OH}, \mathrm{O}_{2}{ }^{\bullet-}$ and reducing power, but the $\mathrm{Fe}^{2+}$ chelating ability is lower than other enzymatic hydrolysis methods [198]. In addition, the chemical analysis process is easily affected by the detection environment. In particular, the assays of FRAP, TEAC, and Folin-Ciocalteu reagent for evaluating PAs need to be performed under acidic, neutral, and alkaline conditions, respectively [193]. The DPPH assays based on the principle of ET is also susceptible to $\mathrm{pH}$, and DPPH radicals are only soluble in organic solvents and are not suitable for evaluating water-soluble antioxidants. Therefore, in the evaluation of in vitro activity, an appropriate evaluation scheme should be selected as comprehensively as possible or according to the antioxidant indicators that the experiment focuses on. Vasquez-Villanueva et al. applied the inhibition of the peroxidation of linoleic acid as indicators to evaluate the antioxidant activity of peach kernel protein hydrolysate and peptides at each separation stage by DPPH radical assay, ABTS radical assay, ${ }^{\bullet} \mathrm{OH}$ assay, FRAP, and finally identified 18 peptides with antioxidant activity [199]. Tovar-Perez et al. evaluated the antioxidant activity of glutelin hydrolysate from cocoa (Theobroma cacao L.) seed and peptides by DPPH, ABTS and ORAC, and purified the peptides with high DPPH and ABTS radical scavenging ability $\left(E C_{50}=237.48\right.$ and $19.29 \mu \mathrm{g} / \mathrm{mL}$, respectively) [200]. It is worth noting that the model system of bulk oil, oil-in-water emulsion and muscle food can provide the expected physical and chemical environment of foods, which is an important means to evaluate the antioxidant effect of PAs in the food matrix [201].

\subsection{In Vitro Biological Evaluation}

In vitro biological evaluation, that is, introducing a ROS-induced system $\left(\mathrm{H}_{2} \mathrm{O}_{2}\right.$, lipophilic tert-butyl hydroperoxide $(t$-BHP), and 2-azobis-(2-amidinopropane) dihydrochloride (AAPH) etc.) into a biological subcellular or animal tissue homogenate system to simulate oxygen stress damage in the body, and measuring some oxidative and non-oxidative indicators to reflect the functional activity of PAs [202]. Since the cells of humans and other organisms are often exposed to different 
oxidants, the cell model is closer to the environment in the organism. An appropriate in vitro biological model can provide a simple and inexpensive method for evaluating the bio-availability of PAs [203,204]. Cells of target organs (such as the liver, brain, or muscles) that are often exposed to oxidative stress are generally selected as cells in vitro. Different model cells were selected according to the application purpose of the antioxidants, so as to evaluate the capacity of antioxidants to inhibit a specific oxidative stress response in the organism [205]. Currently, Erythrocytes, Human hepatoma (HepG2) cells, Caco-2 cell monolayer, Pheochromocytoma (PC-12) cells, Human colon adenocarcinoma (HT-29) cells, Human hepatocyte-derived (C3A) cells, Human leukemia T (Jurkat) cells, Human umbilical vein endothelial cells (HUVECs), etc., have been used in the evaluation of various antioxidants [206,207]. The evaluation indicators of PAs in cell models mainly include the promotion of endogenous enzymes and non-enzymatic antioxidants (SOD, catalase (CAT), GSH-Px and GSH) and the inhibition of oxidation products (ROS, MDA, oxidized glutathione (GSSG) (Table 3). $\mathrm{H}_{2} \mathrm{O}_{2}$-induced Caco-2 and HT-29 cell models show that the penta-peptide (NRYHE) derived from chickpea protein hydrolysate can up-regulate the activity of antioxidant enzymes (CAT, glutathione reductase (GR) and GSH-Px) in cells, and it was observed that peptide treatment elevated the expression of Nrf2 mRNA and several relative genes NQO1, HO-1, $\gamma$-GCS regulated by Nrf2 compared to the positive control [208]. Yi et al. studied the effect of soybean peptides on $\mathrm{H}_{2} \mathrm{O}_{2}$-induced oxidative stress in HepG2 cells [209]. The results showed that soybean peptides inhibited the production of $\mathrm{H}_{2} \mathrm{O}_{2}$-induced ROS, MDA and GSSG in HepG2 cells, prevented the reduction of GSH and up-regulated the activity of cellular antioxidant enzymes (SOD, CAT and GSH-Px), which are expected to protect and regulate the body under oxidative stress. Wang et al. evaluated the changes of antioxidant activity of cooked eggs in a simulated human GI digestion model in vitro, and used the level of ROS in rat aortic vascular smooth muscle cells (VSMC) measured by dihydroethidium staining as an evaluation indicator [210]. The purified three peptides (DSTRTQ, ESKPV and DVYSF) with antioxidant activity have the potential to regulate vascular function. Cellular antioxidant activity (CAA) is a quantitative analysis method to measure the ability of target compounds to quench peroxy radical in HepG2 cells, which provide evidence of the comparison of antioxidant capacity of different peptides (Table 3). The protective effect of cells under oxidative stress is also used in the evaluation of PAs, usually by 3-(4,5-dimethylthiazol-2-yl)-2,5-diphenyltetrazolium bromide (MTT) colorimetric assay. Several studies have evaluated the viability of cell models exposed to PAs without oxidative stress treatment. These experiments are used to verify whether the PAs studied are cytotoxic and provide the concentration of non-cytotoxic peptides for subsequent experiments. Using ORAC as an evaluation target, the PA CCCCSVQK was purified and identified from water-soluble protein extracts of Hanwoo beef [211]. Subsequently, the MTT method was applied to determine its effect on the proliferation of human colorectal carcinoma cells (HCT116). The results showed that CCCCSVQK dose-dependently inhibited the growth of HCT116 cells, and the maximum inhibition rate $(25.24 \%)$ was obtained at $250 \mu \mathrm{g} / \mathrm{mL}$. Peptides extracted from hazelnut protein hydrolysate can inhibit ROS synthesis in HUVECs, and have strong antioxidant and cytoprotective effects on Ang-induced oxidative damage, which can be used as an antioxidant in the food and pharmaceutical industries [63]. 
Table 3. Evaluation of in vitro cell model of peptidic antioxidants ${ }^{1}$.

\begin{tabular}{|c|c|c|c|c|}
\hline Source & Peptide & Cellular Model & Cellular Effect & Ref \\
\hline Whey protein & Hydrophobic peptide & $\mathrm{H}_{2} \mathrm{O}_{2}$-treated PC12 cells & $\begin{array}{l}\text { Increased cell survival rate }(19.3 \%) \text {; decreased cell } \\
\text { death }(28.6 \%)\end{array}$ & [212] \\
\hline Indian squid protein & WCTSVS & $\begin{array}{l}\mathrm{H}_{2} \mathrm{O}_{2} \text {-treated breast cancer cells } \\
\text { (MCF7) }\end{array}$ & Decreased intracellular ROS & [213] \\
\hline Soybean protein & FDPAL & $\mathrm{H}_{2} \mathrm{O}_{2}$-treated HeLa cells & Increased cell viability under oxidative stress & [214] \\
\hline Soybean protein & SHECN & AAPH-treated HepG2 cells & Possessed CAA (776.22 $\mu \mathrm{mol} \mathrm{QE} / 100 \mathrm{~g})$ & [215] \\
\hline Pine nut meal protein & KWFCT, Ac-QWFCT & AAPH-treated HepG2 cells & Possessed CAA $(612.8,916.3 \mu \mathrm{mol} Q \mathrm{QE} / 100 \mathrm{~g})$ & [216] \\
\hline Pine nut protein & QDHCH & $\begin{array}{c}\text { AAPH-treated/ } \mathrm{H}_{2} \mathrm{O}_{2} \text {-treated } \\
\text { HepG2 cells }\end{array}$ & $\begin{array}{c}\text { Possessed CAA (3051.84 } \mu \mathrm{mol} \text { QE/100 g); } \\
\text { increased SOD, GSH-Px, CAT, GR activities; } \\
\text { decreased MDA content } \\
\text { increased cell viability under oxidative stress }\end{array}$ & [217] \\
\hline Hanwoo beef protein & CCCCSVQK & $\begin{array}{l}\text { Human colorectal carcinoma } \\
\text { cells (HCT116) }\end{array}$ & Inhibits the proliferation of HCT116 cells & [211] \\
\hline Chinese Baijiu & PHP & AAPH-treated HepG2 cells & $\begin{array}{c}\text { Increased SOD, GSH-Px, CAT activities; increased } \\
\text { GSH content; decreased MDA, GSSG content; } \\
\text { decreased intracellular ROS levels }\end{array}$ & [218] \\
\hline Rapeseed protein & WDHHAPQLR & $\mathrm{H}_{2} \mathrm{O}_{2}$-treated HUVECs cells & Reduced cell apoptosis & [207] \\
\hline Perilla seed protein & YL, FY & $\mathrm{H}_{2} \mathrm{O}_{2}$-treated HepG2 cells & Reduced cell apoptosis & [219] \\
\hline Lupin protein confer & Peptides with $\mathrm{Mw}<3 \mathrm{kDa}$ & $\mathrm{H}_{2} \mathrm{O}_{2}$-treated HepG2 cells & $\begin{array}{l}\text { Increased cell survival rate; decreased intracellular } \\
\text { ROS levels; increased SOD, GSH-Px }\end{array}$ & [220] \\
\hline Soybean protein & $\begin{array}{c}\text { IYVVDLR; IYVFVR, VVFVDRL, } \\
\text { VIYVVDLR }\end{array}$ & $\mathrm{H}_{2} \mathrm{O}_{2}$-treated Caco- 2 cells & $\begin{array}{c}\text { Increased CAT, GR activity (IYVVDLR, IYVFVR); } \\
\text { increased GSH content (IYVVDLR, IYVFVR, } \\
\text { VVFVDRL); increased cell viability under } \\
\text { oxidative stress (IYVVDLR, IYVFVR, VVFVDRL); } \\
\text { decreased MDA content; decreased intracellular } \\
\text { ROS levels }\end{array}$ & [221] \\
\hline
\end{tabular}


Table 3. Cont.

\begin{tabular}{|c|c|c|c|c|}
\hline Source & Peptide & Cellular Model & Cellular Effect & Ref \\
\hline Fermented grain (Jiupei) & VNP, YGD & AAPH-treated HepG2 cells & $\begin{array}{c}\text { Increased SOD, GSH-Px, CAT activities; decreased } \\
\text { intracellular ROS levels; decreased MDA, GSSG } \\
\text { content; increased GSH content }\end{array}$ & [222] \\
\hline Defatted walnut meal & $\begin{array}{c}\text { VEGNLQVLRPR, } \\
\text { LAGNPHQQQQN, } \\
\text { HNLDTQTESDV, } \\
\text { AGNDGFEYVTLK, } \\
\text { QQRQQQGL, } \\
\text { AELQVVDHLGQTV, } \\
\text { EQEEEESTGRMK, } \\
\text { WSVWEQELEDR }\end{array}$ & $\mathrm{H}_{2} \mathrm{O}_{2}$-treated SHSY5Y cells & $\begin{array}{l}\text { Decreased intracellular ROS levels (ex } \\
\text { WSVWEQELEDR); } \\
\text { increased cell viability under oxidative stress }\end{array}$ & [223] \\
\hline Mulberry leaf protein & SVL, EAVQ, RDY & AAPH-treated HepG2 cells & $\begin{array}{l}\text { Possessed CAA (1706, 1501, } 2204 \mu \mathrm{mol} Q \mathrm{QE} / 100 \mathrm{~g}) \\
\text { inhibited oxidant-induced hemolysis (RDY: 92\%) }\end{array}$ & [224] \\
\hline Egg white protein & VYLPR & $\mathrm{H}_{2} \mathrm{O}_{2}$-treated HEK-293 cells & $\begin{array}{l}\text { Increased cell viability under oxidative stress } \\
\text { (97.45\%); increased SOD, GSH-Px activities; } \\
\text { decreased MDA; inhibit LDH activity }\end{array}$ & [225] \\
\hline $\begin{array}{l}\text { Collagen from sea } \\
\text { cucumber }\end{array}$ & Peptides with $\mathrm{Mw}<1 \mathrm{kDa}$ & $\mathrm{H}_{2} \mathrm{O}_{2}$-treated RAW264.7 cells & $\begin{array}{l}\text { Promote cell proliferation; decreased intracellular } \\
\text { ROS levels; decreased intracellular ROS levels; } \\
\text { increased SOD, GSH-Px activities; decreased MDA }\end{array}$ & [226] \\
\hline $\begin{array}{l}\text { Collagen of Redlip } \\
\text { Croaker }\end{array}$ & $\begin{array}{l}\text { GPEGPMGLE, EGPFGPEG, } \\
\text { GFIGPTE }\end{array}$ & $\mathrm{H}_{2} \mathrm{O}_{2}$-treated HepG2 cells & $\begin{array}{l}\text { Decreased intracellular ROS levels; decreased } \\
\text { MDA; increased SOD, GSH-Px, CAT activities }\end{array}$ & [227] \\
\hline Fermented milk & $\begin{array}{l}\text { NTVPAKSCQAQPTTM, } \\
\text { EDELQDKIHPF, } \\
\text { QGPIVLNPWDQVKR, } \\
\text { APSFSDIPNPIGSENSE }\end{array}$ & T-BHP-treated Caco-2 cells & $\begin{array}{l}\text { Increased cell viability under oxidative stress; } \\
\text { decreased intracellular ROS levels }\end{array}$ & [129] \\
\hline Whey protein & Peptides with $\mathrm{Mw} \leq 3 \mathrm{kDa}$ & Menadione-treated IEC-18 cells & Increased cell viability under oxidative stress $(88 \%)$ & [228] \\
\hline
\end{tabular}

${ }^{1}$ The complete meaning of the abbreviations in the table: cellular antioxidant activity (CAA); lipophilic tert-butyl hydroperoxide ( $t$-BHP), water-soluble 2,2-azobis-(2-amidinopropane) dihydrochloride (AAPH); reactive oxygen species (ROS); glutathione peroxidase (GSH-Px); malondialdehyde (MDA); superoxide dismutase (SOD); catalase (CAT); oxidized glutathione (GSSG); glutathione (GSH); molecular weight (Mw). 
Due to the complexity of the human digestive system and internal environment, the evaluation of PAs should also consider its stability in GI digestion, cell penetration, and the action in the biological environment. At the same time, because the human body may produce similar peptides when digesting the same protein, new PAs released from food proteins through simulated digestion may be more physiologically significant [229-231]. The Pepsin-Pancreatin system is commonly used to simulate GI digestion in vitro, which is often used to evaluate the stability of PAs in GI [232]. The experiment of the Caco-2 cell model demonstrated that the transmembrane transport mode of wheat germ peptide $(\mathrm{Mw}<1 \mathrm{kDa})$ is mainly passive transport, which can exert an effective antioxidant effect through intestinal epithelium [233]. Three different cases of hydrophobic casein peptides were sequentially processed through simulated GI digestion and Caco-2 cell model, and the peptide nitrogen was used to evaluate the bioavailability (BA) and remaining peptide content [234]. The results showed that the treated highly hydrophobic peptides had excellent BA and certain residual antioxidant activity, but had poor stability in GI digestion, and two GI-resistant peptides (NTVP and IV) were identified from this component.

\subsection{In Vivo Evaluation}

The in vivo evaluation of antioxidants mainly includes the indirect determination of the degree of protection of bioactivity substances against DNA oxidative damage, lipid peroxidation, protein oxidative damage, and mitochondrial oxidative damage based on the determination of oxidative stress biomarkers, and the direct measurement of the antioxidant level of the antioxidant defense system [235]. Currently, only a few studies have evaluated the effect of food-derived PAs in animal models. In the model, the animal was fed the tested substance, and the antioxidant activity of the test substance in the organisms was evaluated by comparing the experimental group and the control. Khaled et al. verified that Sardine protein hydrolysates (SPHs) have high DPPH free radical scavenging activity and metal-chelating activity through in vitro chemical experiments, and conducted a series of animal experiments on them [236,237]. From the results, SPH treatment can reduce the concentration of MDA and increase the activity of antioxidant enzymes (SOD, GSH-Px, CAT) and high-density lipoprotein cholesterol.

Active peptides can inhibit or block lipid membranes peroxidation caused by excessive accumulation of free radicals, protect protein and nucleic acid structures in cells from oxidative damage, thereby improving antioxidant capacity and inhibiting the occurrence of oxidative fatigue. Ding et al. found that jellyfish collagen hydrolysate improved the anti-fatigue ability of mice and increased the activity of SOD and GSH-Px in mice [238]. The decline of exercise endurance is the most direct and objective indicator of fatigue. Guo et al. prepared sea-horse peptides by enzymatic hydrolysis that the DPPH radical scavenging rate is $71.89 \pm 1.50 \%$ and ${ }^{\bullet} \mathrm{OH}$ scavenging rate is $75.53 \pm$ $0.98 \%$ [239]. Furthermore, the team evaluated the anti-fatigue activity of sea-horse peptides in mice through the swimming exhaustion experiment according to the changes in blood glucose, blood lactic acid, serum urea nitrogen and liver glycogen content in mice before and after exercise. The results show that sea-horse peptides have anti-fatigue activity and its anti-fatigue effect is dose-dependent.

Generally, the in vivo experiment is more sensitive and closer to the actual system of the organism, but it has the disadvantages of long experiment time, high cost and cumbersome process. This is why the evaluation of the antioxidants usually carried out in the order in vitro to in vivo, and from the chemical environment to the biological environment. Meanwhile, the toxicity and dose-response of antioxidant peptides should be considered to ensure the authenticity and reliability of the results.

\section{Potential Application of Food-Derived PAs}

\subsection{Functional Ingredients to Stabilize Food Quality}

Since mixed peptides or pure peptides can reduce oxidative changes during food processing or storage, they are expected to be added as functional ingredients to food systems [240]. The protective 
effect of PAs on the food matrix is mainly reflected in the inhibition of lipid oxidation of high-fat foods (such as food emulsions, meats, sauces, beverages), thereby delaying the loss of food nutrients and suppressing the production of harmful substances [241,242]. Studies have shown that certain PAs derived from foods (such as squid [243], mussels [244], oysters [15], shrimp muscle [245]) have the same or better ability to inhibit lipid peroxidation as the fat-soluble antioxidant $\alpha$-tocopherol. In the linoleic acid model system, the tripeptide (WPP) isolated from the clam protein hydrolysate showed lipid peroxidation reduction ability similar to GSH [246]. In the sardine minced meat model system, the squid protein hydrolysate prepared by Papain has similar lipid oxidation inhibition ability as ascorbic acid [247]. Zein hydrolysate has been proven to effectively inhibit lipid oxidation, reduce the production of hydrogen peroxide and TBARS, and significantly improve the oxidative stability of model oils [248]. Moreover, this hydrolysate has no negative effect on the quality of the emulsion, and may become an effective antioxidant in food emulsion [249]. QITEGEDGGG (Caragana seed protein source) can effectively inhibit the oxidation of linoleic acid (inhibition ratio: $60.37 \%$ ), delay the auto-oxidation rate of walnut oil, and produce a synergistic effect with tertiary butylhydroquinone (TBHQ) and vitamin C [250]. It is worth noting that the antioxidant properties of pure peptides have been verified by re-synthetic peptides. Milk-derived protein hydrolysates and peptides can be used to prevent lipid oxidation in muscle foods $[251,252]$. Casein calcium peptide $(2.0 \%)$ added to beef paste homogenate can inhibit about $70 \%$ of the lipid oxidation in the homogenate, which helps to prevent the generation of odors in meat products, thereby extending the shelf life [253]. The crude peptide extract from lamb ham significantly reduces the content of thiobarbituric acid reactive substances and cross-linking of proteins in lamb cake, and also improves the color, texture and microbial stability of the product [254]. The protein hydrolysates and peptides derived from marine biological such as Kirin gelatin skin [255], Amur sturgeon skin gelatin [256], Heilongjiang fish skin [257], silver carp [258,259], shellfish [260], can be used as bifunctional ingredients (antioxidants and cryoprotectants) to delay the lipid oxidation and protein denaturation of the seafood products [261]. Gelatin hydrolysates prepared from cuttlefish skin $(0.5 \mathrm{mg} / \mathrm{g})$ can delay lipid oxidation of turkey sausage at $4{ }^{\circ} \mathrm{C}$ for up to 10 days [262]. After dipping with the hydrolysis of shrimp waste, the whole crocodile fish skin can maintain the color at $4{ }^{\circ} \mathrm{C}$ for 10 days [263]. The protein hydrolysate processed by Savinase or Protamex by-product of eel can be added to the meat emulsion as a preservative to inhibit the growth of microorganisms within 11 days at $4{ }^{\circ} \mathrm{C}$ [264]. The gelatin water-soluble chitosan film containing squid Maillard peptide can effectively preserve the fresh bluefin tuna and prolong the storage period to 8 days at $4 \pm 1{ }^{\circ} \mathrm{C}$ [265]. Compared with protein hydrolysates and mixed peptides, the preparation process of pure peptides is more complicated and the cost is relatively high, resulting in less research on the maintenance of food quality. Therefore, the application of PAs as functional components must fully consider their cost. In addition, the protein hydrolysis process or the selection of specific peptides may cause changes in their composition and structure, and may produce other adverse substances that affect food quality. Therefore, before a PA is commercialized, it is necessary to evaluate its stability during food processing and storage and the potential safety or sensory problems it may cause [266].

\subsection{Human Health Promotion and Disease Treatment}

PAs have broad application prospects in promoting human health and preventing and treating diseases related to oxidative damage [267]. Some dietary supplements or skincare products that use PAs (such as GSH, carnosine, and anserine) as the main functional ingredients have been commercialized. However, most of the PAs extracted from food proteins are still in the experimental stage. As described in Sections 4.2 and 4.3, some cell models and animal experiments have shown that PAs have a significant protective effect on cells under oxidative stress. PAs have the effects of anti-fatigue, improving memory and vascular health [268], protecting the liver [269,270], reducing ROS-related pro-inflammatory reactions $[221,271]$ and preventing atherosclerosis $[272,273]$, which provides a basis for their application in nutritious foods, functional foods, dietary supplements and other fields [274]. Cuttlefish-purified peptides can obviously inhibit the oxidation process of linoleic acid, 
effectively protect the DNA damage induced by $\bullet \mathrm{OH}$ radicals, and have no toxic effect to cells at higher concentrations [159]. In addition, some studies have confirmed that PAs have certain potential in the treatment of cancer [275], malaria [276], hypertension [277,278] and blood diseases [224], and are expected to become therapeutic drugs. Bioactive peptides derived from rapeseed protein (LY, RALP, GHS) can significantly inhibit the secretion of NO, il-6 and tumor necrosis factor stimulated by lipopolysaccharide, and then repair the damage of spontaneously hypertensive cells caused by oxidative stress, which has potential application value in protecting the body from oxidative and inflammatory damage [279]. At present, due to the lack of animal model experiments and human clinical trials, the research progress of antioxidant peptides in terms of bioavailability is minimal, which limits their commercialization process. On the other hand, in the application process of the food matrix, the influence of food ingredients and processing conditions on the bioavailability of PAs, as well as the production cost, biological activity, efficacy and safety of peptide-containing foods should be considered [280-282]. Before the development of large-scale foods containing PAs, it must be confirmed that the addition of these peptides will not cause negative effects and still retain their antioxidant activity.

\section{Conclusions}

PAs have considerable potential application value in human health promotion, disease treatment and food preservation. At present, the preparation, performance evaluation and commercial production of food protein-derived PAs have received extensive attention from researchers, which has greatly promoted the development of the field of natural antioxidants. However, due to the immature research in various fields of PAs, further development is needed. Enzymatic hydrolysis is still the main way to produce PAs from food proteins. The introduction of bioinformatics technology is expected to gradually develop the preparation of natural PAs into a predictable and controllable process. In addition, the combination of in silico and biochemical experiments is expected to become a promising strategy for developing and modifying food protein-derived PAs. Meanwhile, due to the advantages of unique food flavor and reduced production costs, microbial fermentation and other food processing methods have become indispensable means for the development of PAs, but its related mechanism of action still needs further research. The role of PAs in the prevention and treatment of oxidative stress-related diseases has been controversial. Animal experiments on bioavailability and food safety of PAs are still relatively few. Therefore, the actual effects and side effects of PAs should be further studied before clinical trials. In recent years, using food processing by-products as raw materials for the production of PAs has become a hot spot for researchers and related companies, which can effectively reduce production costs and environmental pressure. In addition, it is of great practical significance to effectively optimize and improve the processes of hydrolysis, separation and purification in industrial production to improve production efficiency.

Author Contributions: M.P. provided the idea and complete Sections 1 and 6; K.L. coordinated and organized the writing of the entire manuscript and completed the Section 1, Section 2, and Section 4 (M.P. and K.L. contributed to this article equally); J.Y. completed the Section 3 and checked the language and format of the manuscript; S.L. and S.W. (Shan Wang) completed the part of Section 5; S.W. (Shuo Wang) provided the framework of the paper and finally checked the quality of the article. All authors have read and agreed to the published version of the manuscript.

Funding: This research was funded by the National Key Research and Development Program of China (No. 2017YFF0211002), National Natural Science Foundation of China (No. 31972147), Tianjin Technical Expert Project (No. 19JCTPJC52700), Project of Tianjin Science and Technology Plan (No. 18ZYPTJC00020), and the Open Project Program of State Key Laboratory of Food Nutrition and Safety, Tianjin University of Science and Technology (SKLFNS-KF-201907). The APC was funded by the Open Project Program of State Key Laboratory of Food Nutrition and Safety, Tianjin University of Science and Technology (SKLFNS-KF-201907).

Conflicts of Interest: The authors declare no conflict of interest. 


\section{References}

1. Harman, D. Aging: A theory based on free radical and radiation chemistry. J. Gerontol. 1956, 11, $298-300$. [CrossRef] [PubMed]

2. Halliwell, B.; Gutteridge, J.M. Oxygen free radicals and iron in relation to biology and medicine: Some problems and concepts. Arch. Biochem. Biophys. 1986, 246, 501-514. [CrossRef]

3. Weidinger, A.; Kozlov, A.V. Biological activities of reactive oxygen and nitrogen species: Oxidative stress versus signal transduction. Biomolecules 2015, 5, 472-484. [CrossRef] [PubMed]

4. Valencia, E.; Marin, A.; Hardy, G. Glutathione-Nutritional and pharmacological viewpoints: Part II. Nutrition 2001, 17, 485-486. [CrossRef]

5. Poljšak, B.; Šuput, D.; Milisav, I. Achieving the balance between ROS and antioxidants: When to use the synthetic antioxidants. Oxidative Med. Cell. Longev. 2013, 2013, 956792. [CrossRef] [PubMed]

6. Ye, Z.W.; Zhang, J.; Townsend, D.M.; Tew, K.D. Oxidative stress, redox regulation and diseases of cellular differentiation. Biochim. Biophys. Acta 2014, 1850, 1607-1621. [CrossRef] [PubMed]

7. Najafian, L.; Babji, A.S. Production of bioactive peptides using enzymatic hydrolysis and identification antioxidative peptides from patin (Pangasius sutchi) sarcoplasmic protein hydolysate. J. Funct. Foods 2014, 9, 280-289. [CrossRef]

8. Luca, M.; Luca, A.; Calandra, C. The role of oxidative damage in the pathogenesis and progression of alzheimer's disease and vascular dementia. Oxidative Med. Cell. Longev. 2015, 2015, 1-8. [CrossRef]

9. Young, I.S.; Woodside, J.V. Antioxidants in health and disease. J. Clin. Pathol. 2001, 54, 176-186. [CrossRef]

10. Wu, J.; Huo, J.; Huang, M.; Zhao, M.; Luo, X.; Sun, B. Structural characterization of a tetrapeptide from sesame flavor-type baijiu and its preventive effects against AAPH-induced oxidative stress in HepG2 cells. J. Agric. Food Chem. 2017, 65, 10495-10504. [CrossRef]

11. Sies, H. Oxidative stress: Oxidants and antioxidants. Exp. Physiol. 1997, 82, 291-295. [CrossRef] [PubMed]

12. Boissonneault, G.A.; Hardwick, T.A.; Bogardus, S.L.; Chan, W.K.; Tatum, V.; Glauert, H.P.; Chow, C.K.; Decker, E.A. Interactions between carnosine and vitamin $\mathrm{E}$ in mammary cancer risk determination. Nutr. Res. 1998, 18, 723-733. [CrossRef]

13. Rizzello, C.G.; De Angelis, M.; Di Cagno, R.; Camarca, A.; Silano, M.; Losito, I.; De Vincenzi, M.; De Bari, M.D.; Palmisano, F.; Maurano, F.; et al. Highly efficient gluten degradation by lactobacilli and fungal proteases during food processing: New perspectives for celiac disease. Appl. Environ. Microbiol. 2007, 73, 4499-4507. [CrossRef] [PubMed]

14. Decker, E.A.; Chan, W.K.; Livisay, S.A.; Butterfield, D.A.; Faustman, C. Interactions between carnosine and the different redox states of myoglobin. J. Food Sci. 1995, 60, 1201-1204. [CrossRef]

15. Qian, Z.J.; Jung, W.K.; Byun, H.G.; Kim, S.K. Protective effect of an antioxidative peptide purified from gastrointestinal digests of oyster, Crassostrea gigas against free radical induced DNA damage. Bioresour. Technol. 2008, 99, 3365-3371. [CrossRef]

16. Elias, R.J.; Kellerby, S.S.; Decker, E.A. Antioxidant activity of proteins and peptides. Crit. Rev. Food Sci. Nutr. 2008, 48, 430-441. [CrossRef]

17. Nimse, S.; Pal, D. Free radicals, natural antioxidants, and their reaction mechanisms. RSC Adv. 2015, 5, 27986-28006. [CrossRef]

18. Shahidi, F.; Zhong, Y. Novel antioxidants in food quality preservation and health promotion. Eur. J. Lipid Sci. Technol. 2010, 112, 930-940. [CrossRef]

19. Yust, M.M.; Millan-Linares, M.D.; Alcaide-Hidalgo, J.M.; Millan, F.; Pedroche, J. Hypocholesterolemic and antioxidant activities of chickpea (Cicer arietinum L.) protein hydrolysates. J. Sci. Food Agric. 2012, 92, 1994-2001. [CrossRef]

20. Chakrabarti, S.; Jahandideh, F.; Wu, J. Food-derived bioactive peptides on inflammation and oxidative stress. BioMed Res. Int. 2014, 2014, 1-11. [CrossRef]

21. Park, S.Y.; Je, J.Y.; Ahn, C.B. Protein hydrolysates and ultrafiltration fractions obtained from krill (Euphausia superba): Nutritional, functional, antioxidant, and ACE-inhibitory characterization. J. Aquat. Food Prod. Technol. 2016, 25, 1266-1277. [CrossRef]

22. Sila, A.; Bougatef, A. Antioxidant peptides from marine by-products: Isolation, identification and application in food systems. A review. J. Funct. Foods 2016, 21, 10-26. [CrossRef] 
23. Hu, F.; Ci, A.T.; Wang, H.; Zhang, Y.Y.; Zhang, J.G.; Thakur, K.; Wei, Z. Identification and hydrolysis kinetic of a novel antioxidant peptide from pecan meal using Alcalase. Food Chem. 2018, 261, 301-310. [CrossRef] [PubMed]

24. Lemes, A.C.; Sala, L.; Ores, J.D.; Braga, A.R.C.; Egea, M.B.; Fernandes, K.F. A review of the latest advances in encrypted bioactive peptides from protein-rich waste. Int. J. Mol. Sci. 2016, 17, 950. [CrossRef] [PubMed]

25. Monari, S.; Ferri, M.; Russo, C.; Prandi, B.; Tedeschi, T.; Bellucci, P.; Zambrini, A.V.; Donati, E.; Tassoni, A. Enzymatic production of bioactive peptides from scotta, an exhausted by-product of ricotta cheese processing. PLOS ONE 2019, 14, e0226834. [CrossRef]

26. Lorenzo, J.M.; Munekata, P.E.S.; Gómez, B.; Barba, F.J.; Mora, L.; Pérez-Santaescolástica, C.; Toldrá, F. Bioactive peptides as natural antioxidants in food products-A review. Trends Food Sci. Technol. 2018, 79, 136-147. [CrossRef]

27. Power, O.; Jakeman, P.M.; Fitzgerald, R.J. Antioxidative peptides: Enzymatic production, in vitro and in vivo antioxidant activity and potential applications of milk-derived antioxidative peptides. Amino Acids 2012, 44, 797-820. [CrossRef]

28. Stefanucci, A.; Mollica, A.; Macedonio, G.; Dall'Acqua, S.; Ahmed, A.A.; Novellino, E. Exogenous opioid peptides derived from food proteins and their possible uses as dietary supplements: A critical review. Food Rev. Int. 2016, 34, 70-86. [CrossRef]

29. Bamdad, F.; Wu, J.; Chen, L. Effects of enzymatic hydrolysis on molecular structure and antioxidant activity of barley hordein. J. Cereal Sci. 2011, 54, 20-28. [CrossRef]

30. Shazly, A.B.; He, Z.; El-Aziz, M.A.; Zeng, M.; Zhang, S.; Qin, F.; Chen, J. Fractionation and identification of novel antioxidant peptides from buffalo and bovine casein hydrolysates. Food Chem. 2017, 232, 753-762. [CrossRef]

31. Wang, B.; Gong, Y.D.; Li, Z.R.; Yu, D.; Chi, C.F.; Ma, J.Y. Isolation and characterisation of five novel antioxidant peptides from ethanol-soluble proteins hydrolysate of spotless smoothhound (Mustelus griseus) muscle. J. Funct. Foods 2014, 6, 176-185. [CrossRef]

32. Ren, Y.; Wu, H.; Li, X.F.; Lai, F.; Xiao, X. Purification and characterization of high antioxidant peptides from duck egg white protein hydrolysates. Biochem. Biophys. Res. Commun. 2014, 452, 888-894. [CrossRef] [PubMed]

33. Kou, X.; Gao, J.; Xue, Z.; Zhang, Z.; Wang, H.; Wang, X. Purification and identification of antioxidant peptides from chickpea (Cicer arietinum L.) albumin hydrolysates. LWT Food Sci. Technol. 2013, 50, 591-598. [CrossRef]

34. Torres-Fuentes, C.; Alaiz, M.; Vioque, J. Chickpea chelating peptides inhibit copper-mediated lipid peroxidation. J. Sci. Food Agric. 2014, 94, 3181-3188. [CrossRef]

35. Intiquilla, A.; Jimenez-Aliaga, K.L.; Zavaleta, A.I.; Arnao, I.; Peña, C.; Chavez-Hidalgo, E.L.; Hernández-Ledesma, B. Erythrina edulis (pajuro) seed protein: A new source of antioxidant peptides. Nat. Prod. Commun. 2016, 11, 781-786. [CrossRef] [PubMed]

36. Suetsuna, K.; Chen, J.R. Isolation and characterization of peptides with antioxidant activity derived from wheat gluten. Food Sci. Technol. Res. 2002, 8, 227-230. [CrossRef]

37. Zhu, B.; He, H.; Hou, T. A comprehensive review of corn protein-derived bioactive peptides: Production, characterization, bioactivities, and transport pathways. Compr. Rev. Food Sci. Food Saf. 2018, 18, 329-345. [CrossRef]

38. Piu', L.D.; Tassoni, A.; Serrazanetti, D.I.; Ferri, M.; Babini, E.; Tagliazucchi, D.; Gianotti, A. Exploitation of starch industry liquid by-product to produce bioactive peptides from rice hydrolyzed proteins. Food Chem. 2014, 155, 199-206. [CrossRef]

39. Di Bernardini, R.; Harnedy, P.A.; Bolton, D.; Kerry, J.; O’Neill, E.; Mullen, A.; Hayes, M. Antioxidant and antimicrobial peptidic hydrolysates from muscle protein sources and by-products. Food Chem. 2011, 124, 1296-1307. [CrossRef]

40. Liu, R.; Xing, L.; Fu, Q.; Zhou, G.; Zhang, W. A review of antioxidant peptides derived from meat muscle and by-products. Antioxidants 2016, 5, 32. [CrossRef]

41. Yang, J.I.; Liang, W.S.; Chow, C.J.; Siebert, K.J. Process for the production of tilapia retorted skin gelatin hydrolysates with optimized antioxidative properties. Process. Biochem. 2009, 44, 1152-1157. [CrossRef]

42. Pihlanto, A. Antioxidative peptides derived from milk proteins. Int. Dairy J. 2006, 16, 1306-1314. [CrossRef] 
43. Benedé, S.; Molina, E. Chicken egg proteins and derived peptides with antioxidant properties. Foods 2020, 9, 735. [CrossRef] [PubMed]

44. Zhang, Y.; Zhang, H.; Wang, L.; Guo, X.; Qi, X.; Qian, H. Influence of the degree of hydrolysis (DH) on antioxidant properties and radical-scavenging activities of peanut peptides prepared from fermented peanut meal. Eur. Food Res. Technol. 2011, 232, 941-950. [CrossRef]

45. Kleekayai, T.; Le Gouic, A.V.; Deracinois, B.; Cudennec, B.; FitzGerald, R.J. In vitro characterisation of the antioxidative properties of whey protein hydrolysates generated under $\mathrm{pH}$ - and Non $\mathrm{pH}$-controlled onditions. Foods 2020, 9, 582. [CrossRef]

46. El-Fattah, A.M.A.; Sakr, S.S.; El-Dieb, S.M.; Elkashef, H.A.S. Bioactive peptides with ACE-I and antioxidant activity produced from milk proteolysis. Int. J. Food Prop. 2016, 20, 3033-3042. [CrossRef]

47. Harnedy, P.A.; O'Keeffe, M.B.; Fitzgerald, R.J. Fractionation and identification of antioxidant peptides from an enzymatically hydrolysed Palmaria palmata protein isolate. Food Res. Int. 2017, 100, 416-422. [CrossRef]

48. Zhao, Q.; Xiong, H.; Selomulya, C.; Chen, X.D.; Zhong, H.; Wang, S.; Sun, W.; Zhou, Q. Enzymatic hydrolysis of rice dreg protein: Effects of enzyme type on the functional properties and antioxidant activities of recovered proteins. Food Chem. 2012, 134, 1360-1367. [CrossRef]

49. Wattanasiritham, L.; Theerakulkait, C.; Wickramasekara, S.; Maier, C.S.; Stevens, J.F. Isolation and identification of antioxidant peptides from enzymatically hydrolyzed rice bran protein. Food Chem. 2016, 192, 156-162. [CrossRef]

50. Darewicz, M.; Borawska, J.; Pliszka, M. Carp proteins as a source of bioactive peptides-An in Silico approach. Czech. J. Food Sci. 2016, 34, 111-117. [CrossRef]

51. Nwachukwu, I.D.; Aluko, R.E. Structural and functional properties of food protein-derived antioxidant peptides. J. Food Biochem. 2019, 43, e12761. [CrossRef]

52. Esfandi, R.; Willmore, W.G.; Tsopmo, A. Peptidomic analysis of hydrolyzed oat bran proteins, and their in vitro antioxidant and metal chelating properties. Food Chem. 2018, 279, 49-57. [CrossRef]

53. Shang, W.-H.; Tang, Y.; Su, S.-Y.; Han, J.-R.; Yan, J.-N.; Wu, H.-T.; Zhu, B.-W. In silico assessment and structural characterization of antioxidant peptides from major yolk protein of sea urchin Strongylocentrotus nudus. Food Funct. 2018, 9, 6435-6443. [CrossRef] [PubMed]

54. Iwaniak, A.; Darewicz, M.; Mogut, D.; Minkiewicz, P. Elucidation of the role of in silico methodologies in approaches to studying bioactive peptides derived from foods. J. Funct. Foods 2019, 61, 103486. [CrossRef]

55. Liu, J.; Jin, Y.; Lin, S.; Jones, G.S.; Chen, F. Purification and identification of novel antioxidant peptides from egg white protein and their antioxidant activities. Food Chem. 2015, 175, 258-266. [CrossRef] [PubMed]

56. Wang, L.S.; Huang, J.; Chen, Y.L.; Huang, M.; Zhou, G.H. Identification and characterization of antioxidant peptides from enzymatic hydrolysates of duck meat. J. Agric. Food Chem. 2015, 63, 3437-3444. [CrossRef]

57. Torres-Fuentes, C.; Contreras-Gámez, M.; Recio, I.; Alaiz, M.; Vioque, J. Identification and characterization of antioxidant peptides from chickpea protein hydrolysates. Food Chem. 2015, 180, 194-202. [CrossRef]

58. Yan, Q.; Huang, L.H.; Sun, Q.; Jiang, Z.; Wu, X. Isolation, identification and synthesis of four novel antioxidant peptides from rice residue protein hydrolyzed by multiple proteases. Food Chem. 2015, 179, 290-295. [CrossRef]

59. Ngoh, Y.Y.; Gan, C.Y. Enzyme-assisted extraction and identification of antioxidative and $\alpha$-amylase inhibitory peptides from Pinto beans (Phaseolus vulgaris cv. Pinto). Food Chem. 2016, 190, 331-337. [CrossRef]

60. Agrawal, H.; Joshi, R.; Gupta, M. Isolation, purification and characterization of antioxidative peptide of pearl millet (Pennisetum glaucum) protein hydrolysate. Food Chem. 2016, 204, 365-372. [CrossRef]

61. Ma, S.; Zhang, M.; Beta, T.; Dong, T.; Bao, X.; Li, Z. Purification and structural identification of glutelin peptides derived from oats. Cyta-J. Food 2017, 15, 508-515. [CrossRef]

62. Zhang, J.; Liu, S.; Zhang, Y.; Lu, Y.; Wang, M.; Wang, G.; Liu, X. Purification and antioxidant ability of peptide from egg in sea cucumber apostichopus japonicus. Int. J. Food Prop. 2016, 20, 306-317. [CrossRef]

63. Liu, C.; Ren, D.; Li, J.; Fang, L.; Wang, J.; Liu, J.; Min, W. Cytoprotective effect and purification of novel antioxidant peptides from hazelnut (C. heterophylla Fisch) protein hydrolysates. J. Funct. Foods 2018, 42, 203-215. [CrossRef]

64. Liu, B.; Aisa, H.A.; Yili, A. Isolation and identification of two potential antioxidant peptides from sheep abomasum protein hydrolysates. Eur. Food Res. Technol. 2018, 244, 1615-1625. [CrossRef] 
65. Intiquilla, A.; Jimenez-Aliaga, K.L.; Guzmán, F.; Alvarez, C.A.; Zavaleta, A.I.; Izaguirre, V.; Hernández-Ledesma, B. Novel antioxidant peptides obtained by alcalase hydrolysis of Erythrina edulis (pajuro) protein. J. Sci. Food Agric. 2018, 99, 2420-2427. [CrossRef] [PubMed]

66. Agrawal, H.; Joshi, R.; Gupta, M. Purification, identification and characterization of two novel antioxidant peptides from finger millet (Eleusine coracana) protein hydrolysate. Food Res. Int. 2018, 120, 697-707. [CrossRef]

67. Kim, H.S.; Lee, W.; Lee, J.H.; Sanjeewa, K.; Fernando, I.; Ko, S.C.; Lee, S.H.; Kim, Y.T.; Jeon, Y.J. Purification and identification of an antioxidative peptide from digestive enzyme hydrolysis of cutlassfish muscle. J. Aquat. Food Prod. Technol. 2018, 27, 934-944. [CrossRef]

68. Kim, S.S.; Ahn, C.B.; Moon, S.W.; Je, J.Y. Purification and antioxidant activities of peptides from sea squirt (Halocynthia roretzi) protein hydrolysates using pepsin hydrolysis. Food Biosci. 2018, 25, 128-133. [CrossRef]

69. Bordbar, S.; Ebrahimpour, A.; Zarei, M.; Hamid, A.A.; Saari, N. Alcalase-generated proteolysates of stone fish (Actinopyga lecanora) flesh as a new source of antioxidant peptides. Int. J. Food Prop. 2018, 21, 1541-1559. [CrossRef]

70. Karami, Z.; Peighambardoust, S.H.; Hesari, J.; Akbari-Adergani, B. Response surface methodology to optimize hydrolysis parameters in production of antioxidant peptides from wheat germ protein by Alcalase digestion and identification of antioxidant peptides by LC-MS/MS. J. Agric. Sci. Tech. Iran. 2019, 21, 829-844.

71. Lu, X.; Zhang, L.; Sun, Q.; Song, G.; Huang, J. Extraction, identification and structure-activity relationship of antioxidant peptides from sesame (Sesamum indicum L.) protein hydrolysate. Food Res. Int. 2018, 116, 707-716. [CrossRef] [PubMed]

72. Jin, H.X.; Xu, H.P.; Li, Y.; Zhang, Q.W.; Xie, H. Preparation and evaluation of peptides with potential antioxidant activity by microwave assisted enzymatic hydrolysis of collagen from sea cucumber acaudina molpadioides obtained from Zhejiang Province in China. Mar. Drugs 2019, 17, 169. [CrossRef]

73. Luo, X.; Fei, Y.; Xu, Q.; Lei, T.; Mo, X.; Wang, Z.; Zhang, L.; Mou, X.; Li, H. Isolation and identification of antioxidant peptides from tartary buckwheat albumin (Fagopyrum tataricum Gaertn) and their antioxidant activities. J. Food Sci. 2020, 85, 611-617. [CrossRef] [PubMed]

74. Yang, J.; Huang, J.; Dong, X.; Zhang, Y.; Zhou, X.; Huang, M.; Zhou, G. Purification and identification of antioxidant peptides from duck plasma proteins. Food Chem. 2020, 319, 126534. [CrossRef] [PubMed]

75. Vanvi, A.; Tsopmo, A. Pepsin digested oat bran proteins: Separation, antioxidant activity, and identification of new peptides. J. Chem. 2016, 2016, 8216378. [CrossRef]

76. Ran, L.Y.; Su, H.N.; Zhao, G.Y.; Gao, X.; Zhou, M.Y.; Wang, P.; Zhao, H.L.; Xie, B.B.; Zhang, X.Y.; Chen, X.L.; et al. Structural and mechanistic insights into collagen degradation by a bacterial collagenolytic serine protease in the subtilisin family. Mol. Microbiol. 2013, 90, 997-1010. [CrossRef]

77. Yang, X.; Liu, D.; Liu, D.; Wu, R.; Wu, C.; Zhang, J.; Huang, J.; Liao, B.; He, H. Optimization of collagenase production by pseudoalteromonas sp. SJN2 and application of collagenases in the preparation of antioxidative hydrolysates. Mar. Drugs 2017, 15, 377. [CrossRef]

78. Neto, Y.A.A.H.; Rosa, J.C.; Cabral, H. Peptides with antioxidant properties identified from casein, whey, and egg albumin hydrolysates generated by two novel fungal proteases. Prep. Biochem. Biotechnol. 2019, 49, 639-648. [CrossRef]

79. Zhang, Y.; Duan, X.; Zhuang, Y. Purification and characterization of novel antioxidant peptides from enzymatic hydrolysates of tilapia (Oreochromis niloticus) skin gelatin. Peptides 2012, 38, 13-21. [CrossRef]

80. Ren, Y.; Wu, H.; Li, X.; Lai, F.; Zhao, G.; Xiao, X. A two-step, one-pot enzymatic method for preparation of duck egg white protein hydrolysates with high antioxidant activity. Appl. Biochem. Biotechnol. 2013, 172, 1227-1240. [CrossRef]

81. Rios, G.; Belleville, M.P.; Paolucci, D.; Marcano, J.S. Progress in enzymatic membrane reactors-A review. J. Membr. Sci. 2004, 242, 189-196. [CrossRef]

82. Wang, H.; Wang, J.; Lv, Z.; Liu, Y.; Lu, F. Preparing oligopeptides from broken rice protein by ultrafiltration-coupled enzymatic hydrolysis. Eur. Food Res. Technol. 2013, 236, 419-424. [CrossRef]

83. Merz, M.; Eisele, T.; Claaßen, W.; Appel, D.; Rabe, S.; Stressler, T.; Fischer, L. Continuous long-term hydrolysis of wheat gluten using a principally food-grade enzyme membrane reactor system. Biochem. Eng. J. 2015, 99, 114-123. [CrossRef]

84. Martin-Orue, C.; Henry, G.; Bouhallab, S. Tryptic hydrolysis of kappa-caseinomacropepitide: Control of the enzymatic reaction in a continuous membrane reactor. Enzyme Microb. Tech. 1999, 24, 173-180. [CrossRef] 
85. Giorno, L.; Drioli, E. Biocatalytic membrane reactors: Applications and perspectives. Trends Biotechnol. 2000, 18, 339-349. [CrossRef]

86. Ewert, J.; Claaßen, W.; Stressler, T.; Fischer, L. An innovative two-step enzymatic membrane bioreactor approach for the continuous production of antioxidative casein hydrolysates with reduced bitterness. Biochem. Eng. J. 2019, 150, 107261. [CrossRef]

87. Tanasković, S.J.; Luković, N.; Grbavčić, S.; Stefanović, A.; Jovanovic, J.R.; Bugarski, B.; Knežević-Jugović, Z.D. Production of egg white protein hydrolysates with improved antioxidant capacity in a continuous enzymatic membrane reactor: Optimization of operating parameters by statistical design. J. Food Sci. Technol. 2017, 55, 128-137. [CrossRef]

88. Wang, Y.; Chen, H.; Wang, J.; Xing, L. Preparation of active corn peptides from zein through double enzymes immobilized with calcium alginate-chitosan beads. Process. Biochem. 2014, 49, 1682-1690. [CrossRef]

89. Neto, J.M.D.; Maciel, J.D.C.; Campos, J.F.; Junior, L.B.D.C.; Marques, D.D.A.V.; Lima, C.D.A.; Porto, A.L.F. Optimization ofPenicillium aurantiogriseumprotease immobilization on magnetic nanoparticles for antioxidant peptides' obtainment. Prep. Biochem. Biotechnol. 2017, 47, 644-654. [CrossRef]

90. Siddiqui, I.; Husain, Q.; Azam, A. Exploring the antioxidant effects of peptides from almond proteins using PAni-Ag-GONC conjugated trypsin by improving enzyme stability \& applications. Int. J. Biol. Macromol. 2020, 158, 150-158. [CrossRef]

91. Uluko, H.; Zhang, S.; Liu, L.; Tsakama, M.; Lu, J.; Lv, J. Effects of thermal, microwave, and ultrasound pretreatments on antioxidative capacity of enzymatic milk protein concentrate hydrolysates. J. Funct. Foods 2015, 18, 1138-1146. [CrossRef]

92. Zhang, M.; Huang, T.S.; Mu, T.H. Production and in vitro gastrointestinal digestion of antioxidant peptides from enzymatic hydrolysates of sweet potato protein affected by pretreatment. Plant. Foods Hum. Nutr. 2019, 74, 225-231. [CrossRef] [PubMed]

93. Bruno, S.F.; Kudre, T.G.; Narayan, B. Effects of different pretreatments and proteases on recovery, umami taste compound contents and antioxidant potentials of Labeo rohita head protein hydrolysates. J. Food Sci. Technol. 2019, 56, 1966-1977. [CrossRef] [PubMed]

94. Quan, T.H.; Benjakul, S. Production and characterisation of duck albumen hydrolysate using enzymatic process. Int. J. Food Sci. Technol. 2019, 54, 3015-3023. [CrossRef]

95. Zhu, K.X.; Su, C.Y.; Guo, X.N.; Peng, W.; Zhou, H.M. Influence of ultrasound during wheat gluten hydrolysis on the antioxidant activities of the resulting hydrolysate. Int. J. Food Sci. Technol. 2011, 46, 1053-1059. [CrossRef]

96. Girgih, A.T.; Chao, D.; Lin, L.; He, R.; Jung, S.; Aluko, R.E. Enzymatic protein hydrolysates from high pressure-pretreated isolated pea proteins have better antioxidant properties than similar hydrolysates produced from heat pretreatment. Food Chem. 2015, 188, 510-516. [CrossRef]

97. Wang, K.; Wang, Y.; Lin, S.; Liu, X.; Yang, S.; Jones, G.S. Analysis of DPPH inhibition and structure change of corn peptides treated by pulsed electric field technology. J. Food Sci. Technol. 2014, 52, 4342-4350. [CrossRef]

98. Huang, Y.; Ruan, G.H.; Qin, Z.; Li, H.; Zheng, Y. Antioxidant activity measurement and potential antioxidant peptides exploration from hydrolysates of novel continuous microwave-assisted enzymolysis of the Scomberomorus niphonius protein. Food Chem. 2017, 223, 89-95. [CrossRef]

99. Ketnawa, S.; Liceaga, A.M. Effect of microwave treatments on antioxidant activity and antigenicity of fish frame protein hydrolysates. Food Bioprocess. Technol. 2016, 10, 582-591. [CrossRef]

100. Kangsanant, S.; Murkovic, M.; Thongraung, C. Antioxidant and nitric oxide inhibitory activities of tilapia (Oreochromis niloticus) protein hydrolysate: Effect of ultrasonic pretreatment and ultrasonic-assisted enzymatic hydrolysis. Int. J. Food Sci. Technol. 2014, 49, 1932-1938. [CrossRef]

101. Abadía-García, L.; Castaño-Tostado, E.; Ozimek, L.; Romero-Gómez, S.; Ozuna, C.; Amaya-Llano, S.L. Impact of ultrasound pretreatment on whey protein hydrolysis by vegetable proteases. Innov. Food Sci. Emerg. Technol. 2016, 37, 84-90. [CrossRef]

102. Li, X.; Da, S.; Li, C.; Xue, F.; Zang, T. Effects of high-intensity ultrasound pretreatment with different levels of power output on the antioxidant properties of alcalase hydrolyzates from Quinoa (Chenopodium quinoa Willd) protein isolate. Cereal Chem. J. 2018, 95, 518-526. [CrossRef]

103. Walters, M.E.; Willmore, W.G.; Tsopmo, A. Antioxidant, physicochemical, and cellular secretion of glucagon-like peptide-1 properties of oat bran protein hydrolysates. Antioxidants 2020, 9, 557. [CrossRef] [PubMed] 
104. Ikram, S.; Zhang, H.; Ahmed, M.S.; Wang, J. Ultrasonic pretreatment improved the antioxidant potential of enzymatic protein hydrolysates from highland barley brewer's spent grain (BSG). J. Food Sci. 2020, 85, 1045-1059. [CrossRef]

105. Liang, Q.; Ren, X.; Ma, H.; Li, S.; Xu, K.; Oladejo, A.O. Effect of low-frequency ultrasonic-assisted enzymolysis on the physicochemical and antioxidant properties of corn protein hydrolysates. J. Food Qual. 2017, 2017, 1-10. [CrossRef]

106. Hemker, A.K.; Nguyen, L.T.; Karwe, M.; Salvi, D. Effects of pressure-assisted enzymatic hydrolysis on functional and bioactive properties of tilapia (Oreochroniis niloticus) by-product protein hydrolysates. LWT Food Sci. Technol. 2020, 122, 109003. [CrossRef]

107. Zhang, T.; Jiang, B.; Miao, M.; Mu, W.; Li, Y. Combined effects of high-pressure and enzymatic treatments on the hydrolysis of chickpea protein isolates and antioxidant activity of the hydrolysates. Food Chem. 2012, 135, 904-912. [CrossRef]

108. Al-Ruwaih, N.; Ahmed, J.; Mulla, M.Z.; Arfat, Y.A. High-pressure assisted enzymatic proteolysis of kidney beans protein isolates and characterization of hydrolysates by functional, structural, rheological and antioxidant properties. LWT Food Sci. Technol. 2019, 100, 231-236. [CrossRef]

109. Dong, X.H.; Li, J.; Jiang, G.X.; Li, H.Y.; Zhao, M.M.; Jiang, Y. Effects of combined high pressure and enzymatic treatments on physicochemical and antioxidant properties of peanut proteins. Food Sci. Nutr. 2019, 7, 1417-1425. [CrossRef]

110. Bamdad, F.; Bark, S.; Kwon, C.H.; Suh, J.W.; Sunwoo, H. Anti-Inflammatory and antioxidant properties of peptides released from beta-Lactoglobulin by high hydrostatic pressure-assisted enzymatic hydrolysis. Molecules 2017, 22, 949. [CrossRef]

111. Guan, H.; Diao, X.; Jiang, F.; Han, J.; Kong, B. The enzymatic hydrolysis of soy protein isolate by Corolase PP under high hydrostatic pressure and its effect on bioactivity and characteristics of hydrolysates. Food Chem. 2018, 245, 89-96. [CrossRef] [PubMed]

112. Franck, M.; Perreault, V.; Suwal, S.; Marciniak, A.; Bazinet, L.; Doyen, A. High hydrostatic pressure-assisted enzymatic hydrolysis improved protein digestion of flaxseed protein isolate and generation of peptides with antioxidant activity. Food Res. Int. 2019, 115, 467-473. [CrossRef] [PubMed]

113. Wang, J.; Wang, K.; Lin, S.; Zhao, P.; Jones, G.; Trang, H.; Liu, J.; Ye, H. Improvement of antioxidant activity of peptides with molecular weights ranging from 1 to $10 \mathrm{kDa}$ by PEF technology. Int. J. Boil. Macromol. 2012, 51, 244-249. [CrossRef]

114. Lin, S.; Guo, Y.; You, Q.; Yin, Y.; Liu, J. Preparation of antioxidant peptide from egg white protein and improvement of its activities assisted by high-intensity pulsed electric field. J. Sci. Food Agric. 2011, 92, 1554-1561. [CrossRef] [PubMed]

115. Lin, S.; Jin, Y.; Liu, M.; Yang, Y.; Zhang, M.; Guo, Y.; Jones, G.; Liu, J.; Yin, Y. Research on the preparation of antioxidant peptides derived from egg white with assisting of high-intensity pulsed electric field. Food Chem. 2013, 139, 300-306. [CrossRef]

116. Lin, S.; Liang, R.; Li, X.; Xing, J.; Yuan, Y. Effect of pulsed electric field (PEF) on structures and antioxidant activity of soybean source peptides-SHCMN. Food Chem. 2016, 213, 588-594. [CrossRef]

117. Lin, S.; Liang, R.; Xue, P.; Zhang, S.; Liu, Z.; Dong, X. Antioxidant activity improvement of identified pine nut peptides by pulsed electric field (PEF) and the mechanism exploration. LWT Food Sci. Technol. 2017, 75, 366-372. [CrossRef]

118. Zhou, Q.C.; Liu, N.; Feng, C.X. Research on the effect of papain co-extrusion on pea protein and enzymolysis antioxidant peptides. J. Food Process. Preserv. 2017, 41, e13301. [CrossRef]

119. Zhang, M.; Huang, T.; Mu, T. Production and characterisation of antioxidant peptides from sweet potato protein by enzymatic hydrolysis with radio frequency pretreatment. Int. J. Food Sci. Technol. 2019, 55, 2352-2358. [CrossRef]

120. Zhang, X.; Wang, L.; Chen, Z.; Li, Y.; Luo, X.; Li, Y. Effect of high energy electron beam on proteolysis and antioxidant activity of rice proteins. Food Funct. 2020, 11, 871-882. [CrossRef]

121. Kim, J.; Whang, J.; Kim, K.; Koh, J.; Suh, H.J. Preparation of corn gluten hydrolysate with angiotensin I converting enzyme inhibitory activity and its solubility and moisture sorption. Process. Biochem. 2004, 39, 989-994. [CrossRef] 
122. Moreno-Montoro, M.; Olalla-Herrera, M.; Rufián-Henares, J.A.; Martínez, R.G.; Miralles, B.; Bergillos, T.; Navarro-Alarcón, M.; Jauregi, P. Antioxidant, ACE-inhibitory and antimicrobial activity of fermented goat milk: Activity and physicochemical property relationship of the peptide components. Food Funct. 2017, 8 , 2783-2791. [CrossRef] [PubMed]

123. Marti-Quijal, F.J.; Tornos, A.; Príncep, A.; Luz, C.; Meca, G.; Tedeschi, P.; Ruiz, M.J.; Barba, F.J. Impact of fermentation on the recovery of antioxidant bioactive compounds from sea bass byproducts. Antioxidants 2020, 9, 239. [CrossRef] [PubMed]

124. Jung, W.K.; Rajapakse, N.; Kim, S.K. Antioxidative activity of a low molecular weight peptide derived from the sauce of fermented blue mussel, Mytilus edulis. Eur. Food Res. Technol. 2004, 220, 535-539. [CrossRef]

125. Fan, J.; Zhang, Y.; Chang, X.; Saito, M.; Li, Z. Changes in the radical scavenging activity of bacterial-type douchi, a traditional fermented soybean product, during the primary fermentation process. Biosci. Biotechnol. Biochem. 2009, 73, 2749-2753. [CrossRef] [PubMed]

126. De Lima, M.D.F.; Da Silva, R.A.; Silva, M.F.; Da Silva, P.A.B.; Costa, R.M.P.B.; Teixeira, J.A.C.; Porto, A.L.F.; Cavalcanti, M.T.H. Brazilian kefir-fermented sheep's milk, a source of antimicrobial and antioxidant peptides. Probiotics Antimicrob. Proteins 2017, 10, 446-455. [CrossRef]

127. Aspri, M.; Leni, G.; Galaverna, G.; Papademas, P. Bioactive properties of fermented donkey milk, before and after in vitro simulated gastrointestinal digestion. Food Chem. 2018, 268, 476-484. [CrossRef]

128. Padghan, P.; Mann, B.; Hati, S. Purification and characterization of antioxidative peptides derived from fermented milk (lassi) by lactic cultures. Int. J. Pept. Res. Ther. 2017, 24, 235-249. [CrossRef]

129. Tonolo, F.; Fiorese, F.; Moretto, L.; Folda, A.; Scalcon, V.; Grinzato, A.; Ferro, S.; Arrigoni, G.; Bindoli, A.; Feller, E.; et al. Identification of new peptides from fermented milk showing antioxidant properties: Mechanism of action. Antioxidants 2020, 9, 117. [CrossRef]

130. Najafian, L.; Babji, A.S. Purification and identification of antioxidant peptides from fermented fish sauce (budu). J. Aquat. Food Prod. Technol. 2018, 28, 14-24. [CrossRef]

131. Ohata, M.; Uchida, S.; Zhou, L.; Arihara, K. Antioxidant activity of fermented meat sauce and isolation of an associated antioxidant peptide. Food Chem. 2016, 194, 1034-1039. [CrossRef] [PubMed]

132. Kleekayai, T.; Harnedy, P.A.; O’Keeffe, M.B.; Poyarkov, A.A.; CunhaNeves, A.; Suntornsuk, W.; Fitzgerald, R.J. Extraction of antioxidant and ACE inhibitory peptides from Thai traditional fermented shrimp pastes. Food Chem. 2015, 176, 441-447. [CrossRef] [PubMed]

133. Najafian, L.; Babji, A.S. Fractionation and identification of novel antioxidant peptides from fermented fish (pekasam). J. Food Meas. Charact. 2018, 12, 2174-2183. [CrossRef]

134. He, R.; Ju, X.; Yuan, J.; Wang, L.; Girgih, A.T.; Aluko, R.E. Antioxidant activities of rapeseed peptides produced by solid state fermentation. Food Res. Int. 2012, 49, 432-438. [CrossRef]

135. Moayedi, A.; Hashemi, M.; Safari, M. Valorization of tomato waste proteins through production of antioxidant and antibacterial hydrolysates by proteolytic Bacillus subtilis: Optimization of fermentation conditions. J. Food Sci. Technol. 2015, 53, 391-400. [CrossRef]

136. Mejri, L.; Vásquez-Villanueva, R.; Hassouna, M.; Marina, M.L.; García, M.C. Identification of peptides with antioxidant and antihypertensive capacities by RP-HPLC-Q-TOF-MS in dry fermented camel sausages inoculated with different starter cultures and ripening times. Food Res. Int. 2017, 100, 708-716. [CrossRef]

137. Zhang, Y.; Liu, J.; Lu, X.; Zhang, H.; Wang, L.; Guo, X.; Qi, X.; Qian, H. Isolation and identification of an antioxidant peptide prepared from fermented peanut meal using bacillus subtilis fermentation. Int. J. Food Prop. 2014, 17, 1237-1253. [CrossRef]

138. Jemil, I.; Mora, L.; Nasri, R.; Abdelhedi, O.; Aristoy, M.C.; Hajji, M.; Nasri, M.; Toldrá, F.; Mora, L. A peptidomic approach for the identification of antioxidant and ACE-inhibitory peptides in sardinelle protein hydrolysates fermented by Bacillus subtilis A26 and Bacillus amyloliquefaciens An6. Food Res. Int. 2016, 89, 347-358. [CrossRef]

139. Coda, R.; Rizzello, C.G.; Pinto, D.; Gobbetti, M. Selected lactic acid bacteria synthesize antioxidant peptides during sourdough fermentation of cereal flours. Appl. Environ. Microbiol. 2011, 78, 1087-1096. [CrossRef]

140. Moslehishad, M.; Ehsani, M.R.; Salami, M.; Mirdamadi, S.; Ezzatpanah, H.; Naslaji, A.N.; Moosavi-Movahedi, A.A. The comparative assessment of ACE-inhibitory and antioxidant activities of peptide fractions obtained from fermented camel and bovine milk by Lactobacillus rhamnosus PTCC 1637. Int. Dairy J. 2013, 29, 82-87. [CrossRef] 
141. Raveschot, C.; Cudennec, B.; Coutte, F.; Flahaut, C.; Fremont, M.; Drider, D.; Dhulster, P. Production of bioactive peptides by lactobacillus species: From gene to application. Front. Microbiol. 2018, 9, 2354. [CrossRef] [PubMed]

142. Mirzaei, M.; Mirdamadi, S.; Ehsani, M.R.; Aminlari, M.; Hosseini, E. Purification and identification of antioxidant and ACE-inhibitory peptide from Saccharomyces cerevisiae protein hydrolysate. J. Funct. Foods 2015, 19, 259-268. [CrossRef]

143. Xu, F.Z.; Peng, H.H.; Li, Y.; Li, L.M.; Qian, K.; Ding, X.L. Separation and purification of small peptides from fermented sesame meal and their antioxidant activities. Protein Peptide Lett. 2014, 21, 966-974.

144. Ruan, S.; Li, Y.; Wang, Y.; Huang, S.; Luo, J.; Ma, H.L. Analysis in protein profile, antioxidant activity and structure-activity relationship based on ultrasound-assisted liquid-state fermentation of soybean meal with Bacillus subtilis. Ultrason. Sonochem. 2020, 64, 104846. [CrossRef]

145. Setti, K.; Kachouri, F.; Hamdi, M. Improvement of the antioxidant activity of fenugreek protein isolates by lactococcus lactis fermentation. Int. J. Pept. Res. Ther. 2017, 24, 499-509. [CrossRef]

146. Toldrá, F.; Reig, M.; Aristoy, M.C.; Mora, L. Generation of bioactive peptides during food processing. Food Chem. 2018, 267, 395-404. [CrossRef]

147. Minelli, A.; Conte, C.; Grottelli, S.; Bellezza, I.; Cacciatore, I.; Bolaños, J.P. Cyclo (His-Pro) promotes cytoprotection by activating Nrf2-mediated up-regulation of antioxidant defence. J. Cell. Mol. Med. 2008, 13, 1149-1161. [CrossRef]

148. Samaranayaka, A.G.; Li-Chan, E.C. Food-derived peptidic antioxidants: A review of their production, assessment, and potential applications. J. Funct. Foods 2011, 3, 229-254. [CrossRef]

149. Zhu, C.Z.; Zhang, W.G.; Zhou, G.; Xu, X.L.; Kang, Z.L.; Yin, Y. Isolation and identification of antioxidant peptides from jinhua ham. J. Agric. Food Chem. 2013, 61, 1265-1271. [CrossRef]

150. Escudero, E.; Aristoy, M.C.; Nishimura, H.; Arihara, K.; Toldrá, F. Antihypertensive effect and antioxidant activity of peptide fractions extracted from Spanish dry-cured ham. Meat Sci. 2012, 91, 306-311. [CrossRef]

151. Mora, L.; Escudero, E.; Fraser, P.D.; Aristoy, M.C.; Toldrá, F.; Mora, L. Proteomic identification of antioxidant peptides from 400 to 2500 Da generated in Spanish dry-cured ham contained in a size-exclusion chromatography fraction. Food Res. Int. 2014, 56, 68-76. [CrossRef]

152. Gallego, M.; Mora, L.; Toldrá, F. Characterisation of the antioxidant peptide AEEEYPDL and its quantification in Spanish dry-cured ham. Food Chem. 2018, 258, 8-15. [CrossRef] [PubMed]

153. Garem, A.; Daufin, G.; Maubois, J.L. Selective separation of amino acids with a charged inorganic nanofiltration membrane:Effect of physicochemical parameters on selectivity. Biotechnol. Bioeng. 1997, 54, 291-302. [CrossRef]

154. Jemil, I.; Abdelhedi, O.; Nasri, R.; Mora, L.; Jridi, M.; Toldrá, F.; Nasri, M.; Aristoy, M.C. Novel bioactive peptides from enzymatic hydrolysate of Sardinelle (Sardinella aurita) muscle proteins hydrolysed by Bacillus subtilis A26 proteases. Food Res. Int. 2017, 100, 121-133. [CrossRef]

155. Capriotti, A.L.; Cavaliere, C.; Foglia, P.; Piovesana, S.; Samperi, R.; Chiozzi, R.Z.; Laganà, A. Development of an analytical strategy for the identification of potential bioactive peptides generated by in vitro tryptic digestion of fish muscle proteins. Anal. Bioanal. Chem. 2014, 407, 845-854. [CrossRef]

156. Holder, A.; Merath, C.; Kulozik, U.; Hinrichs, J. Impact of diffusion, transmembrane pressure and the electrical field on peptide fractionation using cross-flow electro membrane filtration. Int. Dairy J. 2015, 46, 31-38. [CrossRef]

157. Suwal, S.; Ketnawa, S.; Liceaga, A.M.; Huang, J.Y. Electro-membrane fractionation of antioxidant peptides from protein hydrolysates of rainbow trout (Oncorhynchus mykiss) byproducts. Innov. Food Sci. Emerg. Technol. 2018, 45, 122-131. [CrossRef]

158. Mendis, E.; Rajapakse, N.; Byun, H.G.; Kim, S.K. Investigation of jumbo squid (Dosidicus gigas) skin gelatin peptides for their in vitro antioxidant effects. Life Sci. 2005, 77, 2166-2178. [CrossRef]

159. Sudhakar, S.; Nazeer, R.A. Preparation of potent antioxidant peptide from edible part of shortclub cuttlefish against radical mediated lipid and DNA damage. LWT Food Sci. Technol. 2015, 64, 593-601. [CrossRef]

160. Ranathunga, S.; Rajapakse, N.; Kim, S.K. Purification and characterization of antioxidative peptide derived from muscle of conger eel (Conger myriaster). Eur. Food Res. Technol. 2005, 222, 310-315. [CrossRef]

161. Galli, V.; Mazzoli, L.; Luti, S.; Venturi, M.; Guerrini, S.; Paoli, P.; Vincenzini, M.; Granchi, L.; Pazzagli, L. Effect of selected strains of lactobacilli on the antioxidant and anti-inflammatory properties of sourdough. Int. J. Food Microbiol. 2018, 286, 55-65. [CrossRef] [PubMed] 
162. Jang, H.L.; Liceaga, A.M.; Yoon, K.Y. Purification, characterisation and stability of an antioxidant peptide derived from sandfish (Arctoscopus japonicus) protein hydrolysates. J. Funct. Foods 2016, 20, 433-442. [CrossRef]

163. Kurzatkowska, K.; Mielecki, M.; Grzelak, K.; Verwilst, P.; Dehaen, W.; Radecki, J.; Radecka, H. Immobilization of His-tagged kinase JAK2 onto the surface of a plasmon resonce gold disc modified with different copper (II) complexes. Talanta 2014, 130, 336-341. [CrossRef] [PubMed]

164. Canabady-Rochelle, L.L.; Selmeczi, K.; Collin, S.; Pasc, A.; Muhr, L.; Boschi-Muller, S. SPR screening of metal chelating peptides in a hydrolysate for their antioxidant properties. Food Chem. 2018, 239, 478-485. [CrossRef] [PubMed]

165. Malumba, P.; Vanderghem, C.; Deroanne, C.; Béra, F. Influence of drying temperature on the solubility, the purity of isolates and the electrophoretic patterns of corn proteins. Food Chem. 2008, 111, 564-572. [CrossRef]

166. Min, S.G.; Jo, Y.J.; Park, S.H. Potential application of static hydrothermal processing to produce the protein hydrolysates from porcine skin by-products. LWT Food Sci. Technol. 2017, 83, 18-25. [CrossRef]

167. Duan, X.; Ocen, D.; Wu, F.; Li, M.; Yang, N.; Xu, J.; Chen, H.; Huang, L.; Jin, Z.; Xu, X. Purification and characterization of a natural antioxidant peptide from fertilized eggs. Food Res. Int. 2014, 56, 18-24. [CrossRef]

168. Zhang, M.; Mu, T.; Sun, M. Purification and identification of antioxidant peptides from sweet potato protein hydrolysates by Alcalase. J. Funct. Foods 2014, 7, 191-200. [CrossRef]

169. Chen, H.-M.; Muramoto, K.; Yamauchi, F.; Fujimoto, K.; Nokihara, K. Antioxidative properties of histidine-containing peptides designed from peptide fragments found in the digests of a soybean protein. J. Agric. Food Chem. 1998, 46, 49-53. [CrossRef]

170. Yuan, H.; Lv, J.; Gong, J.; Xiao, G.; Zhu, R.; Li, L.; Qiu, J. Secondary structures and their effects on antioxidant capacity of antioxidant peptides in yogurt. Int. J. Food Prop. 2018, 21, 2167-2180. [CrossRef]

171. Matsui, R.; Honda, R.; Kanome, M.; Hagiwara, A.; Matsuda, Y.; Togitani, T.; Ikemoto, N.; Terashima, M. Designing antioxidant peptides based on the antioxidant properties of the amino acid side-chains. Food Chem. 2018, 245, 750-755. [CrossRef] [PubMed]

172. Li, Y.; Jiang, B.; Zhang, T.; Mu, W.; Liu, J. Antioxidant and free radical-scavenging activities of chickpea protein hydrolysate (CPH). Food Chem. 2008, 106, 444-450. [CrossRef]

173. Chakrabarti, S.; Guha, S.; Majumder, K. Food-derived bioactive peptides in human health: Challenges and opportunities. Nutrients 2018, 10, 1738. [CrossRef] [PubMed]

174. Sarmadi, B.H.; Ismail, A. Antioxidative peptides from food proteins: A review. Peptides 2010, 31, $1949-1956$. [CrossRef] [PubMed]

175. Chen, C.; Sun-Waterhouse, D.; Zhao, M.; Sun, W. Beyond antioxidant actions: Insights into the antioxidant activities of tyr-containing dipeptides in aqueous solution systems and liposomal systems. Int. J. Food Sci. Technol. 2020. [CrossRef]

176. Je, J.Y.; Qian, Z.J.; Byun, H.G.; Kim, S.K. Purification and characterization of an antioxidant peptide obtained from tuna backbone protein by enzymatic hydrolysis. Process. Biochem. 2007, 42, 840-846. [CrossRef]

177. Kim, S.Y.; Je, J.Y.; Kim, S.K. Purification and characterization of antioxidant peptide from hoki (Johnius belengerii) frame protein by gastrointestinal digestion. J. Nutr. Biochem. 2007, 18, 31-38. [CrossRef]

178. Bougatef, A.; Nedjar-Arroume, N.; Manni, L.; Ravallec, R.; Barkia, A.; Guillochon, D.; Nasri, M. Purification and identification of novel antioxidant peptides from enzymatic hydrolysates of sardinelle (Sardinella aurita) by-products proteins. Food Chem. 2010, 118, 559-565. [CrossRef]

179. Pouzo, L.; Descalzo, A.; Zaritzky, N.; Rossetti, L.; Pavan, E. Antioxidant status, lipid and color stability of aged beef from grazing steers supplemented with corn grain and increasing levels of flaxseed. Meat Sci. 2016, 111, 1-8. [CrossRef]

180. Freitas, A.C.; Andrade, J.C.; Silva, F.; Rocha-Santos, T.; Duarte, A.C.; Gomes, A. Antioxidative peptides: Trends and perspectives for future research. Curr. Med. Chem. 2013, 20, 4575-4594. [CrossRef]

181. Eftekharzadeh, B.; Khodagholi, F.; Abdi, A.; Maghsoudi, N. Alginate protects NT2 neurons against H2O2-induced neurotoxicity. Carbohydr. Polym. 2010, 79, 1063-1072. [CrossRef]

182. Najafian, L.; Babji, A.S. Isolation, purification and identification of three novel antioxidative peptides from patin (Pangasius sutchi) myofibrillar protein hydrolysates. LWT Food Sci. Technol. 2015, 60, 452-461. [CrossRef] 
183. Bamdad, F.; Chen, L.Y. Antioxidant capacities of fractionated barley hordein hydrolysates in relation to peptide structures. Mol Nutr Food Res. 2013, 57, 493-503. [CrossRef]

184. Zou, T.B.; He, T.P.; Li, H.B.; Tang, H.W.; Xia, E. The structure-activity relationship of the antioxidant peptides from natural proteins. Molecules 2016, 21, 72. [CrossRef] [PubMed]

185. Minkiewicz, P.; Dziuba, J.; Iwaniak, A.; Dziuba, M.; Darewicz, M. BIOPEP database and other programs for processing bioactive peptide sequences. J. AOAC Int. 2008, 91, 965-980. [CrossRef]

186. Tian, M.; Fang, B.; Jiang, L.; Guo, H.Y.; Cui, J.Y.; Ren, F.Z. Structure-activity relationship of a series of antioxidant tripeptides derived from beta-Lactoglobulin using QSAR modeling. Dairy Sci. Technol. 2015, 95, 451-463. [CrossRef]

187. Huang, B.-B.; Lin, H.C.; Chang, Y.-W. Analysis of proteins and potential bioactive peptides from tilapia (Oreochromis spp.) processing co-products using proteomic techniques coupled with BIOPEP database. J. Funct. Foods 2015, 19, 629-640. [CrossRef]

188. Deng, B.C.; Long, H.; Tang, T.; Ni, X.; Chen, J.; Yang, G.; Zhang, F.; Cao, R.; Cao, D.S.; Zeng, M.; et al. Quantitative structure-activity relationship study of antioxidant tripeptides based on model population analysis. Int. J. Mol. Sci. 2019, 20, 995. [CrossRef]

189. Guo, H.; Wang, Y.; He, Q.; Zhang, Y.; Hu, Y.; Wang, Y.; Lin, Z. In silico rational design and virtual screening of antixoidant tripeptides based on 3D-QSAR modeling. J. Mol. Struct. 2019, 1193, 223-230. [CrossRef]

190. Leung, R.; Venus, C.; Zeng, T.; Tsopmo, A. Structure-function relationships of hydroxyl radical scavenging and chromium-VI reducing cysteine-tripeptides derived from rye secalin. Food Chem. 2018, 254, 165-169. [CrossRef]

191. Zhang, Y.; He, S.; Bonneil, E.; Simpson, B.K. Generation of antioxidative peptides from Atlantic sea cucumber using alcalase versus trypsin: In vitro activity, de novo sequencing, and in silico docking for in vivo function prediction. Food Chem. 2020, 306, 125581. [CrossRef]

192. Wu, R.; Wu, C.; Liu, D.; Yang, X.; Huang, J.; Zhang, J.; Liao, B.; He, H.; Li, H. Overview of antioxidant peptides derived from marine resources: The sources, characteristic, purification, and evaluation methods. Appl. Biochem. Biotechnol. 2015, 176, 1815-1833. [CrossRef] [PubMed]

193. Huang, D.; Ou, B.; Prior, R.L. The chemistry behind antioxidant capacity assays. J. Agric. Food Chem. 2005, 53, 1841-1856. [CrossRef] [PubMed]

194. Liao, B.Y.; Zhu, D.Y.; Thakur, K.; Li, L.; Zhang, J.-G.; Wei, Z. Thermal and antioxidant properties of polysaccharides sequentially extracted from mulberry leaves (morus alba L.). Molecules 2017, 22, 2271. [CrossRef] [PubMed]

195. Decker, E.A.; Welch, B. Role of ferritin as a lipid oxidation catalyst in muscle food. J. Agric. Food Chem. 1990, 38, 674-677. [CrossRef]

196. Xie, Z.; Huang, J.; Xu, X.; Jin, Z. Antioxidant activity of peptides isolated from alfafa leaf protein hydrolysate. Food Chem. 2008, 111, 370-376. [CrossRef]

197. Farvin, K.H.S.; Baron, C.P.; Nielsen, N.S.; Jacobsen, C. Antioxidant activity of yoghurt peptides: Part 1-in vitro assays and evaluation in w3 enriched milk. Food Chem. 2010, 123, 1081-1089. [CrossRef]

198. Jin, D.X.; Liu, X.L.; Zheng, X.Q.; Wang, X.J.; He, J. Preparation of antioxidative corn protein hydrolysates, purification and evaluation of three novel corn antioxidant peptides. Food Chem. 2016, 204, 427-436. [CrossRef]

199. Vásquez-Villanueva, R.; Marina, M.L.; García, M.C. Identification by hydrophilic interaction and reversed-phase liquid chromatography-tandem mass spectrometry of peptides with antioxidant capacity in food residues. J. Chromatogr. A 2016, 1428, 185-192. [CrossRef]

200. Tovar-Pérez, E.G.; Guerrero-Becerra, L.; Cervantes, E.L. Antioxidant activity of hydrolysates and peptide fractions of glutelin from cocoa (Theobroma cacao L) seed. Cyta-J. Food 2017, 15, 489-496. [CrossRef]

201. Decker, E.A.; Warner, K.; Richards, M.P.; Shahidi, F. Measuring antioxidant effectiveness in food. J. Agric. Food Chem. 2005, 53, 4303-4310. [CrossRef] [PubMed]

202. Cheli, F.; Baldi, A. Nutrition-based health: Cell-based bioassays for food antioxidant activity evaluation. J. Food Sci. 2011, 76, R197-R205. [CrossRef]

203. Liu, R.H.; Finley, J. Potential cell culture models for antioxidant research. J. Agric. Food Chem. 2005, 53, 4311-4314. [CrossRef] [PubMed]

204. Niki, E. Assessment of Antioxidant Capacity in vitro and in vivo. Free. Radic. Biol. Med. 2010, 49, 503-515. [CrossRef] [PubMed] 
205. Wong, F.C.; Xiao, J.; Wang, S.; Ee, K.Y.; Chai, T.T. Advances on the antioxidant peptides from edible plant sources. Trends Food Sci. Technol. 2020, 99, 44-57. [CrossRef]

206. Zhang, H.; Yin, M.; Huang, L.; Wang, J.; Gong, L.; Liu, J.; Sun, B. Evaluation of the cellular and animal models for the study of antioxidant activity: A review. J. Food Sci. 2017, 82, 278-288. [CrossRef]

207. Xu, F.; Zhang, J.; Wang, Z.; Yao, Y.; Atungulu, G.G.; Ju, X.; Wang, L. Absorption and metabolism of peptide WDHHAPQLR derived from rapeseed protein and inhibition of huvec apoptosis under oxidative stress. J. Agric. Food Chem. 2018, 66, 5178-5189. [CrossRef]

208. Guo, Y.; Zhang, T.; Jiang, B.; Miao, M.; Mu, W. The effects of an antioxidative pentapeptide derived from chickpea protein hydrolysates on oxidative stress in Caco-2 and HT-29 cell lines. J. Funct. Foods 2014, 7, 719-726. [CrossRef]

209. Yi, G.; Din, J.U.; Zhao, F.; Liu, X. Effect of soybean peptides against hydrogen peroxide induced oxidative stress in HepG2 cells via Nrf2 signaling. Food Funct. 2020, 11, 2725-2737. [CrossRef]

210. Wang, J.; Liao, W.; Nimalaratne, C.; Chakrabarti, S.; Wu, J. Purification and characterization of antioxidant peptides from cooked eggs using a dynamic in vitro gastrointestinal model in vascular smooth muscle A7r5 cells. NPJ Sci. Food 2018, 2, 7. [CrossRef]

211. Kim, H.; Yang, S.R.; Jang, A. Anti-proliferative effect of a novel anti-oxidative peptide in hanwoo beef on human colorectal carcinoma cells. Food Sci. Anim. Resour. 2018, 38, 1168-1178. [CrossRef] [PubMed]

212. Zhang, Q.X.; Jin, M.M.; Zhang, L.; Yu, H.X.; Sun, Z.; Lu, R.R. Hydrophobicity of whey protein hydrolysates enhances the protective effect against oxidative damage on PC 12 cells. J. Dairy Res. 2014, 82, 1-7. [CrossRef] [PubMed]

213. Sudhakar, S.; Nazeer, R.A. Structural characterization of an Indian squid antioxidant peptide and its protective effect against cellular reactive oxygen species. J. Funct. Foods 2015, 14, 502-512. [CrossRef]

214. Ma, H.; Liu, R.; Zhao, Z.; Zhang, Z.; Cao, Y.; Ma, Y.; Guo, Y.; Xu, L. A novel peptide from soybean protein isolate significantly enhances resistance of the organism under oxidative stress. PLoS ONE 2016, 11, e0159938. [CrossRef]

215. Yang, R.; Wang, J.; Lin, S.; Ye, H.; Chen, F. In vitroantioxidant activities of the novel pentapeptides Ser-His-Glu-Cys-Asn and Leu-Pro-Phe-Ala-Met and the relationship between activity and peptide secondary structure. J. Sci. Food Agric. 2016, 97, 1945-1952. [CrossRef]

216. Yang, R.; Li, X.; Lin, S.; Zhang, Z.; Chen, F. Identification of novel peptides from 3 to $10 \mathrm{kDa}$ pine nut (Pinus koraiensis) meal protein, with an exploration of the relationship between their antioxidant activities and secondary structure. Food Chem. 2017, 219, 311-320. [CrossRef]

217. Liang, R.; Zhang, Z.; Lin, S. Effects of pulsed electric field on intracellular antioxidant activity and antioxidant enzyme regulating capacities of pine nut (Pinus koraiensis) peptide QDHCH in HepG2 cells. Food Chem. 2017, 237, 793-802. [CrossRef]

218. Wu, J.; Sun, B.; Luo, X.; Zhao, M.; Zheng, F.; Sun, J.; Li, H.; Sun, X.; Huang, M. Cytoprotective effects of a tripeptide from Chinese Baijiu against AAPH-induced oxidative stress in HepG2 cells via Nrf2 signaling. RSC Adv. 2018, 8, 10898-10906. [CrossRef]

219. Yang, J.; Hu, L.; Cai, T.; Chen, Q.; Ma, Q.; Yang, J.; Meng, C.; Hong, J. Purification and identification of two novel antioxidant peptides from perilla (Perilla frutescens L. Britton) seed protein hydrolysates. PLoS ONE 2018, 13, e0200021. [CrossRef]

220. Guo, X.; Shang, W.; Strappe, P.M.; Zhou, Z.; Blanchard, C. Peptides derived from lupin proteins confer potent protection against oxidative stress. J. Sci. Food Agric. 2018, 98, 5225-5234. [CrossRef]

221. Zhang, Q.; Tong, X.; Li, Y.; Wang, H.; Wang, Z.; Qi, B.; Sui, X.; Jiang, L. Purification and characterization of antioxidant peptides from alcalase-hydrolyzed soybean (Glycine max L.) hydrolysate and their cytoprotective effects in human intestinal Caco-2 cells. J. Agric. Food Chem. 2019, 67, 5772-5781. [CrossRef] [PubMed]

222. Jiang, Y.; Zhao, D.; Sun, J.; Luo, X.; Li, H.; Sun, X.; Zheng, F. Analysis of antioxidant effect of two tripeptides isolated from fermented grains (Jiupei) and the antioxidative interaction with 4-methylguaiacol, 4-ethylguaiacol, and vanillin. Food Sci. Nutr. 2019, 7, 2391-2403. [CrossRef] [PubMed]

223. Sheng, J.; Yang, X.; Chen, J.; Peng, T.; Yin, X.; Liu, W.; Liang, M.; Wan, J.; Yang, X. Antioxidative effects and mechanism study of bioactive peptides from defatted walnut (Juglans regia L.) meal hydrolysate. J. Agric. Food Chem. 2019, 67, 3305-3312. [CrossRef] [PubMed] 
224. Sun, C.; Tang, X.; Ren, Y.; Wang, E.; Shi, L.; Wu, X.Y.; Wu, H. Novel antioxidant peptides purified from mulberry (Morus Atropurpurea Roxb.) leaf protein hydrolysates with hemolysis inhibition ability and cellular antioxidant activity. J. Agric. Food Chem. 2019, 67, 7650-7659. [CrossRef]

225. Zhang, B.; Wang, H.; Wang, Y.; Yu, Y.; Liu, J.; Liu, B.; Zhang, T. Identification of antioxidant peptides derived from egg-white protein and its protective effects on $\mathrm{H}_{2} \mathrm{O}_{2}$-induced cell damage. Int. J. Food Sci. Technol. 2019, 54, 2219-2227. [CrossRef]

226. Li, Y.; Li, J.; Lin, S.J.; Yang, Z.; Jin, H.X. Preparation of antioxidant peptide by microwave- assisted hydrolysis of collagen and its protective effect against $\mathrm{H}_{2} \mathrm{O}_{2}$-induced damage of RAW264.7 cells. Mar. Drugs 2019, 17, 642. [CrossRef]

227. Wang, W.Y.; Sun, K.L.; Zhao, G.X.; Chi, C.F.; Wang, B. Antioxidant peptides from collagen hydrolysate of redlip croaker (Pseudosciaena polyactis) scales: Preparation, characterization, and cytoprotective effects on $\mathrm{H}_{2} \mathrm{O}_{2}$-damaged HepG2 cells. Mar. Drugs 2020, 18, 156. [CrossRef]

228. Ballatore, M.B.; Bettiol, M.D.R.; Braber, N.L.V.; Aminahuel, C.A.; Rossi, Y.E.; Petroselli, G.; Erra-Balsells, R.; Cavaglieri, L.R.; Montenegro, M.A. Antioxidant and cytoprotective effect of peptides produced by hydrolysis of whey protein concentrate with trypsin. Food Chem. 2020, 319, 126472. [CrossRef]

229. Lin, X.; Yao, M.; Lu, J.H.; Wang, Y.; Yin, X.; Liang, M.; Yuan, E.; Ren, J. Identification of novel oligopeptides from the simulated digestion of sea cucumber (Stichopus japonicus) to alleviate $\mathrm{A} \beta$ aggregation progression. J. Funct. Foods 2019, 60, 103412. [CrossRef]

230. Vilcacundo, R.; Martínez-Villaluenga, C.; Miralles, B.; Hernández-Ledesma, B. Release of multifunctional peptides from kiwicha (Amaranthus caudatus) protein under in vitro gastrointestinal digestion. J. Sci. Food Agric. 2018, 99, 1225-1232. [CrossRef]

231. Zhang, J.; Du, H.; Zhang, G.; Kong, F.; Hu, Y.; Xiong, S.; Zhao, S. Identification and characterization of novel antioxidant peptides from crucian carp (Carassius auratus) cooking juice released in simulated gastrointestinal digestion by UPLC-MS/MS and in silico analysis. J. Chromatogr. B 2020, 1136, 121893. [CrossRef] [PubMed]

232. Puchalska, P.; Marina, M.L.; García, M.C. Isolation and identification of antioxidant peptides from commercial soybean-based infant formulas. Food Chem. 2014, 148, 147-154. [CrossRef] [PubMed]

233. Zhang, J.; Wen, C.; Li, C.; Duan, Y.; Zhang, H.; Ma, H. Antioxidant peptide fractions isolated from wheat germ protein with subcritical water extraction and its transport across Caco-2 cells. J. Food Sci. 2019, 84, 2139-2146. [CrossRef] [PubMed]

234. Xie, N.; Wang, B.; Jiang, L.; Liu, C.; Li, B. Hydrophobicity exerts different effects on bioavailability and stability of antioxidant peptide fractions from casein during simulated gastrointestinal digestion and Caco-2 cell absorption. Food Res. Int. 2015, 76, 518-526. [CrossRef] [PubMed]

235. Kawamura, T.; Muraoka, I. Exercise-induced oxidative stress and the effects of antioxidant intake from a physiological viewpoint. Antioxidants 2018, 7, 119. [CrossRef] [PubMed]

236. Ben Khaled, H.; Ghlissi, Z.; Chtourou, Y.; Hakim, A.; Ktari, N.; Fatma, M.A.; Barkia, A.; Sahnoun, Z.; Nasri, M. Effect of protein hydrolysates from sardinelle (Sardinella aurita) on the oxidative status and blood lipid profile of cholesterol-fed rats. Food Res. Int. 2012, 45, 60-68. [CrossRef]

237. Ben Khaled, H.; Ktari, N.; Ghorbel-Bellaaj, O.; Jridi, M.; Lassoued, I.; Nasri, M. Composition, functional properties and in vitro antioxidant activity of protein hydrolysates prepared from sardinelle (Sardinella aurita) muscle. J. Food Sci. Technol. 2011, 51, 622-633. [CrossRef]

238. Ding, J.F.; Li, Y.Y.; Xu, J.J.; Su, X.; Gao, X.; Yue, F.P. Study on effect of jellyfish collagen hydrolysate on anti-fatigue and anti-oxidation. Food Hydrocoll. 2011, 25, 1350-1353. [CrossRef]

239. Guo, Z.; Lin, D.; Guo, J.; Zhang, Y.; Zheng, B. In vitro antioxidant activity and in vivo anti-fatigue effect of sea horse (Hippocampus) peptides. Molecules 2017, 22, 482. [CrossRef]

240. Baakdah, M.M.; Tsopmo, A. Identification of peptides, metal binding and lipid peroxidation activities of HPLC fractions of hydrolyzed oat bran proteins. J. Food Sci. Technol. 2016, 53, 3593-3601. [CrossRef]

241. Coelho, M.S.; Aquino, S.D.; Latorres, J.M.; Salas-Mellado, M.D. In vitro and in vivo antioxidant capacity of chia protein hydrolysates and peptides. Food Hydrocoll. 2019, 91, 19-25. [CrossRef]

242. Lin, C.C.; Liang, J.H. Effect of antioxidants on the oxidative stability of chicken breast meat in a dispersion system. J. Food Sci. 2002, 67, 530-533. [CrossRef] 
243. Rajapakse, N.; Mendis, E.; Byun, H.G.; Kim, S.K. Purification and in vitro antioxidative effects of giant squid muscle peptides on free radical-mediated oxidative systems. J. Nutr. Biochem. 2005, 16, 562-569. [CrossRef] [PubMed]

244. Jung, W.K.; Qian, Z.J.; Lee, S.H.; Choi, S.Y.; Sung, N.J.; Byun, H.G.; Kim, S.K. Free radical scavenging activity of a novel antioxidative peptide isolated from in vitro gastrointestinal digests of mytilus coruscus. J. Med. Food 2007, 10, 197-202. [CrossRef]

245. Ngo, D.-H.; Kim, S.K. Marine bioactive peptides as potential antioxidants. Curr. Protein Pept. Sci. 2013, 14, 189-198. [CrossRef]

246. Chi, C.F.; Hu, F.Y.; Wang, B.; Li, T.; Ding, G.F. Antioxidant and anticancer peptides from the protein hydrolysate of blood clam (Tegillarca granosa) muscle. J. Funct. Foods 2015, 15, 301-313. [CrossRef]

247. Sivaraman, B.; Shakila, R.J.; Jeyasekaran, G.; Sukumar, D.; Manimaran, U.; Sumathi, G. Antioxidant activities of squid protein hydrolysates prepared with papain using response surface methodology. Food Sci. Biotechnol. 2016, 25, 665-672. [CrossRef]

248. Shen, Y.; Hu, R.; Li, Y. Antioxidant and emulsifying activities of corn gluten meal hydrolysates in oil-in-water emulsions. J. Am. Oil Chem. Soc. 2019, 97, 175-185. [CrossRef]

249. Li, Y.; Kong, B.; Liu, Q.; Xia, X.; Chen, H. Improvement of the emulsifying and oxidative stability of myofibrillar protein prepared oil-in-water emulsions by addition of zein hydrolysates. Process. Biochem. 2017, 53, 116-124. [CrossRef]

250. Jie, Y.; Zhao, H.; Sun, X.; Lv, X.; Zhang, Z.; Zhang, B. Isolation of antioxidative peptide from the protein hydrolysate of Caragana ambigua seeds and its mechanism for retarding lipid auto-oxidation. J. Sci. Food Agric. 2019, 99, 3078-3085. [CrossRef]

251. Rossini, K.; Noreña, C.P.Z.; Cladera-Olivera, F.; Brandelli, A. Casein peptides with inhibitory activity on lipid oxidation in beef homogenates and mechanically deboned poultry meat. LWT Food Sci. Technol. 2009, 42, 862-867. [CrossRef]

252. Singh, P.; Singh, T.P.; Gandhi, N. Prevention of lipid oxidation in muscle foods by milk proteins and peptides: A review. Food Rev. Int. 2016, 34, 226-247. [CrossRef]

253. Sakanaka, S.; Tachibana, Y.; Ishihara, N.; Juneja, L.R. Antioxidant properties of casein calcium peptides and their effects on lipid oxidation in beef homogenates. J. Agric. Food Chem. 2005, 53, 464-468. [CrossRef] [PubMed]

254. Wang, J.; Lu, S.; Guo, X.; Li, R.; Huang, L. Effect of crude peptide extract from mutton ham on antioxidant properties and quality of mutton patties. J. Food Process. Preserv. 2020, 44, e14436. [CrossRef]

255. Karnjanapratum, S.; Benjakul, S. Cryoprotective and antioxidative effects of gelatin hydrolysate from unicorn leatherjacket skin. Int. J. Refrig. 2015, 49, 69-78. [CrossRef]

256. Nikoo, M.; Benjakul, S.; Xu, X. Antioxidant and cryoprotective effects of Amur sturgeon skin gelatin hydrolysate in unwashed fish mince. Food Chem. 2015, 181, 295-303. [CrossRef]

257. Nikoo, M.; Benjakul, S.; Ehsani, A.; Li, J.; Wu, F.; Yang, N.; Xu, B.; Jin, Z.; Xu, X. Antioxidant and cryoprotective effects of a tetrapeptide isolated from Amur sturgeon skin gelatin. J. Funct. Foods 2014, 7, 609-620. [CrossRef]

258. Qiu, X.; Chen, S.; Dong, S. Effects of silver carp antioxidant peptide on the lipid oxidation of sierra fish fillets (Scomberomorus Niphonius) during frozen storage. J. Food Biochem. 2013, 38, 167-174. [CrossRef]

259. Zhang, L.; Shan, Y.; Hong, H.; Luo, Y.; Hong, X.; Ye, W. Prevention of protein and lipid oxidation in freeze-thawed bighead carp (Hypophthalmichthys nobilis) fillets using silver carp (Hypophthalmichthys molitrix) fin hydrolysates. LWT Food Sci Technol. 2020, 123, 109050. [CrossRef]

260. Harnedy, P.A.; Fitzgerald, R.J. Bioactive peptides from marine processing waste and shellfish: A review. J. Funct. Foods 2012, 4, 6-24. [CrossRef]

261. Nikoo, M.; Benjakul, S. Potential application of seafood-derived peptides as bifunctional ingredients, antioxidant-cryoprotectant: A review. J. Funct. Foods 2015, 19, 753-764. [CrossRef]

262. Jridi, M.; Lassoued, I.; Nasri, R.; Ayadi, M.A.; Nasri, M.; Souissi, N. Characterization and potential use of cuttlefish skin gelatin hydrolysates prepared by different microbial proteases. BioMed Res. Int. 2014, 2014, 1-14. [CrossRef] [PubMed]

263. Dey, S.S.; Dora, K.C. Antioxidative activity of protein hydrolysate produced by alcalase hydrolysis from shrimp waste (Penaeus monodon and Penaeus indicus). J. Food Sci. Technol. 2011, 51, 449-457. [CrossRef] [PubMed] 
264. Bougatef, H.; Krichen, F.; Kobbi, S.; Martínez-Álvarez, Ó.; Nedjar, N.; Bougatef, A.; Sila, A. Physicochemical and biological properties of eel by-products protein hydrolysates: Potential application to meat product preservation. Waste Biomass Valori. 2018, 11, 931-942. [CrossRef]

265. Jiang, W.; Hu, S.; Li, S.; Liu, Y. Evaluation of the preservation effect of gelatin-water soluble chitosan film incorporated with maillard peptides on bluefin tuna (Thunnus thynnus) slices packaging. LWT Food Sci. Technol. 2019, 113, 108294. [CrossRef]

266. Li, X.F.; Yang, R.W.; Lin, S.Y.; Ye, H.Q.; Chen, F. Identification of key volatiles responsible for aroma changes of egg white antioxidant peptides during storage by HS-SPMEGC-MS and sensory evaluation. J. Food Meas. Charact. 2017, 11, 1118-1127. [CrossRef]

267. Mada, S.B.; Ugwu, C.P.; Abarshi, M.M. Health promoting effects of food-derived bioactive peptides: A review. Int. J. Pept. Res. Ther. 2019, 26, 831-848. [CrossRef]

268. Chen, H.; Zhao, M.; Lin, L.; Wang, J.; Sun-Waterhouse, D.X.; Dong, Y.; Zhuang, M.; Su, G. Identification of antioxidative peptides from defatted walnut meal hydrolysate with potential for improving learning and memory. Food Res. Int. 2015, 78, 216-223. [CrossRef]

269. Han, B.K.; Park, Y.; Choi, H.S.; Suh, H. Hepatoprotective effects of soluble rice protein in primary hepatocytes and in mice. J. Sci. Food Agric. 2015, 96, 685-694. [CrossRef]

270. Chakrabarti, S.; Liao, W.; Davidge, S.T.; Wu, J. Milk-derived tripeptides IPP (Ile-Pro-Pro) and VPP (Val-Pro-Pro) differentially modulate angiotensin II effects on vascular smooth muscle cells. J. Funct. Foods 2017, 30, 151-158. [CrossRef]

271. Udenigwe, C.C.; Lu, Y.L.; Han, C.H.; Hou, W.C.; Aluko, R.E. Flaxseed protein-derived peptide fractions: Antioxidant properties and inhibition of lipopolysaccharide-induced nitric oxide production in murine macrophages. Food Chem. 2009, 116, 277-284. [CrossRef]

272. Pan, M.; Huo, Y.; Wang, C.; Zhang, Y.; Dai, Z.; Li, B. Positively charged peptides from casein hydrolysate show strong inhibitory effects on LDL oxidation and cellular lipid accumulation in Raw264.7 cells. Int. Dairy J. 2019, 91, 119-128. [CrossRef]

273. Oh, Y.; Ahn, C.B.; Nam, K.H.; Kim, Y.A.; Yoon, N.Y.; Je, J.Y. Amino acid composition, antioxidant, and cytoprotective effect of blue Mussel (Mytilus edulis) hydrolysate through the inhibition of caspase-3 activation in oxidative stress-mediated endothelial cell injury. Mar. Drugs 2019, 17, 135. [CrossRef] [PubMed]

274. Selamassakul, O.; Laohakunjit, N.; Kerdchoechuen, O.; Yang, L.; Maier, C.S. Bioactive peptides from brown rice protein hydrolyzed by bromelain: Relationship between biofunctional activities and flavor characteristics. J. Food Sci. 2020, 85, 707-717. [CrossRef] [PubMed]

275. Yaghoubzadeh, Z.; Ghadikolaii, F.P.; Kaboosi, H.; Safari, R.; Fattahi, E. Antioxidant activity and anticancer effect of bioactive peptides from rainbow trout (oncorhynchus mykiss) skin hydrolysate. Int. J. Pept. Res. Ther. 2019, 26, 625-632. [CrossRef]

276. Adewole, K.E.; Adebayo, J.O. Antioxidant defense system induced by cysteine-stabilized peptide fraction of aqueous extract of Morinda lucida leaf in selected tissues of Plasmodium berghei -infected mice. J. Integr. Med. 2017, 15, 388-397. [CrossRef]

277. Chalé, F.G.H.; Ruiz, J.C.R.; Fernández, J.J.A.; Ancona, D.A.B.; Campos, M.R.S. ACE inhibitory, hypotensive and antioxidant peptide fractions from Mucuna pruriens proteins. Process. Biochem. 2014, 49, 1691-1698. [CrossRef]

278. Indiano-Romacho, P.; Fernández-Tomé, S.; Amigo, L.; Hernández-Ledesma, B. Multifunctionality of lunasin and peptides released during its simulated gastrointestinal digestion. Food Res. Int. 2019, 125, 108513. [CrossRef]

279. He, R.; Wang, Y.; Yang, Y.; Wang, Z.; Ju, X.; Yuan, J. Rapeseed protein-derived ACE inhibitory peptides LY, RALP and GHS show antioxidant and anti-inflammatory effects on spontaneously hypertensive rats. J. Funct. Foods 2019, 55, 211-219. [CrossRef]

280. Tkaczewska, J.; Borczak, B.; Piątkowska, E.; Kapusta-Duch, J.; Morawska, M.; Czech, T. Effect of protein hydrolysates from carp (Cyprinus carpio) skin gelatine on oxidative stress biomarkers and other blood parameters in healthy rats. J. Funct. Foods 2019, 60, 103411. [CrossRef] 
281. Kamdem, J.P.; Tsopmo, A. Reactivity of peptides within the food matrix. J. Food Biochem. 2017, 43, e12489. [CrossRef] [PubMed]

282. Yuan, J.; Zheng, Y.; Wu, Y.; Chen, H.; Tong, P.; Gao, J. Double enzyme hydrolysis for producing antioxidant peptide from egg white: Optimization, evaluation, and potential allergenicity. J. Food Biochem. 2019, 44, 13113. [CrossRef] [PubMed]

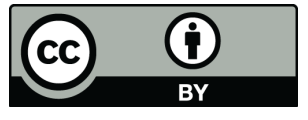

(C) 2020 by the authors. Licensee MDPI, Basel, Switzerland. This article is an open access article distributed under the terms and conditions of the Creative Commons Attribution (CC BY) license (http://creativecommons.org/licenses/by/4.0/). 